\title{
APULEIŮV ZLATÝ OSEL A ANTICKÁ LITERÁRNÍ TRADICE V UMĚNÍ RUDOLFÍNSKÉ DOBY
}

\author{
PAVLA SAVICKÁ \\ Ústav pro dějiny umění Filozofické fakulty Univerzity Karlovy - Národní památkový ústav; \\ p.savicka@gmail.com
}

\begin{abstract}
The Golden Ass of Apuleius and the Classical Literary Tradition in the Visual Arts of the Rudolphine Period

The study follows fortunes of the famous Ancient Roman novel and its impact on the visual arts in the early modern period. Special attention is paid to the Rudolphine art and to the distinctive transformation of the theme of Cupid and Psyche at the court of the emperor. It deals with various changes in meaning of the iconography as it traveled through time, space, and different media and suggests diverse possible readings of works inspired by Apuleius's Golden Ass.

Keywords: Apuleius - Rudolf II - The Golden Ass - Metamorphoses - Cupid - Psyche Bartholomeus Spranger - Joseph Heintz - Matthäus Gundelach
\end{abstract}

„Should you like to go to the Farnesina, Dorothea? It contains celebrated frescoes designed or painted by Raphael, which most persons think it worth while to visit. ",But do you care about them?' was always Dorothea's question. ,They are, I believe, highly esteemed. Some of them represent the fable of Cupid and Psyche, which is probably the romantic invention of a literary period, and cannot, I think, be reckoned as a genuine mythical product. But if you like these wall-paintings we can easily drive thither; and you will then, I think, have seen the chief works of Raphael, any of which it were a pity to omit in a visit to Rome. He is the painter who has been held to combine the most complete grace of form with sublimity of expression. Such at least I have gathered to be the opinion of cognoscenti. "I

Edward Casaubon, hrdina anglického románu Middlemarch, ${ }^{2}$ se pokusil sepsat zásadní knihu, která by shrnula a rozšírila dosavadní poznání antické mytologie. Jeho nemalé ambice vystihl název chystaného díla Key to All Mythologies. Přezíravý neosobní pohled, názor zcela závislý na uznávaných autoritách a nesplnitelné cíle však zničily jeho vědeckou práci stejně jako manželství. Bez emocí přistoupil i k návštěvě římské vily Farnesiny během své svatební cesty. Ze své pozice klasického vzdělance 19. století považoval předlohu slavných Raffaelových fresek za romantický výmysl, který nedosahoval úrovně a vý-

1 George Eliot [Mary Ann Evans], Middlemarch. A Study of Provintial Life, Edinburg-London 1874, s. 145.

2 Poprvé publikován mezi lety 1871-1872. 
znamu Ovidiových nebo Vergiliových děl. Intelektuální snobismus, který je samozřejmě v románu předmětem kritiky, rychle prohlédla i Casaubonova mladá žena a pochopila, že její manžel je nenávratně ztracen v temných zákoutích vlastní badatelské činnosti.

Nehledě na to, jakou roli hraje návštěva Farnesiny v knize Mary Ann Evansové, je Casaubonův odsudek do jisté míry pochopitelný. Mýtus, nebo přesněji prŕiběh či pohádka, o Amorovi a Psýché vychází z díla antického autora afrického původu Lucia Apuleia. Obsahuje ho jeho nejznámější text Zlatý osel, nejstarší latinský román, který se vcelku dochoval do dnešní doby. Sám o sobě by se př́iliš nevymykal jiným oblíbeným vyprávěním o římských bozích a jejich láskách. V rámci celé knihy však jde pouze o jednu z mnoha různě provázaných historek, navíc jedinou mytologického charakteru. Slavný kontroverzní román, známý také pod názvem Metamorfózy, pojednává o neštastné proměně Lucia v osla, peripetiích, které $\mathrm{z}$ toho vzejdou, a jeho vysvobození z oslí podoby díky bohyni Isidě a jejímu kultu. Jde o sérii kratších příběhů, z nichž některé se týkají přímo Lucia a jiné mu pouze někdo vypráví. Často mají samostatnou výraznou pointu a mnohdy také erotický obsah. Spadají do žánru takzvaných milétských povídek, které se staly předlohou mnoha pozdně středověkých a renesančních novel. Do jaké míry jde především o zábavné dílo, nebo jak velký význam má moralizující alegorický výklad, je dodnes předmětem odborné debaty. ${ }^{3}$ Váha těchto sporů leží zejména v interpretaci poslední jedenácté kapitoly, ve které se Lucius promění zpět v člověka díky zásahu bohyně Isidy. Někteří ji považují pouze za rychlé mírně nesystematické ukončení, jiní za klíč k celé knize s mystickým obsahem. ${ }^{4}$

Složitá vypravěčská strategie mohla zmást Edwarda Casaubona i mnohé další. Zlatý osel však nepopiratelně patří k nejvýznamnějším a nejvlivnějším dílům starověké literatury. Nejen díky Raffaelovým malbám pro římskou vilu sienského bankéře Agostina Chigiho je také jednou z nejznámějších antických literárních předloh novověké vizuální kultury. Na první pohled proto není překvapivé ani zvlášt zajímavé, že se Amor a Psýché objevují často také v dílech umělců z okruhu dvora Rudolfa II. Osudy Apuleiova Zlatého osla se však v mnohém liší např́klad od Ovidiových Metamorfóz, hlavního zdroje mytologických námětů v novověku. Na značnou část středověku upadl téměř do úplného zapomnění a jeho text byl nezvěstný. Znovu vyplul na povrch až ve 14 . století a stal se jednou z knih, které zásadně ovlivnily italský humanismus. Znalost Apuleiova díla se šírila z Florencie mezi blízké italské dvory a postupně i za hranice Apeninského poloostrova. Společně s reflexí textu v literatuře se začala objevovat také jeho vizuální zpracování.

Díky jasnému ohnisku v protorenesanční Florencii je možné sledovat poměrně přesně postupný ohlas Zlatého osla napříč Evropou. Ve stěžejní době se navíc díky tisku zásadně proměnily technické možnosti reprodukovatelnosti textu i obrazu, takže cesta Zlatého osla ilustruje jeden z nejdůležitějších kulturních fenoménů novověku. Motivy z Apuleiova románu proto představují ideální východisko pro kulturně-historickou studii. Obzvlášt poutavá se z tohoto pohledu jeví právě díla umělců z okruhu císaře Rudolfa II., která představují jeden z významných mezníků ve vývoji vizuálního zpracování příběhu Amora a Psýché v novověkém umění.

3 Přehled viz například Robert H. Carver, The Protean ass: the "Metamorphoses" of Apuleius from antiquity to the Renaissance, Oxford 2008

4 G. N. Sandy, 'Book 11: Ballast or Anchor?', in: B. L. Hijmans - R. Th. van der Paardt, Aspects of Apuleius' Golden Ass, Groningen 1978, s. 123-40. 
Skupinu dvorních malírů teoreticky vymezil zejména Thomas DaCosta Kaufmann. $\mathrm{V}$ analogii ke škole ve Fontainebleau ji označil jako The School of Prague a zásadně přispěl k jejímu náležitému zařazení do kánonu evropských dějin umění. ${ }^{5}$ Zahrnovala muže několika generací z různých částí Evropy, jejichž zkušenosti, styl i schopnosti se značně lišily. Běžně se k nim řadí také sochaři, grafici a řemeslníci, kteří po nějaký čas svého života pracovali pro Rudolfa II. Z Apuleiova Zlatého osla čerpali především Bartholomeus Spranger, Josef Heintz a Matthäus Gundelach, ale také Adrian de Vries nebo Jan Muller či Hendrik Goltzius. Povaha a vkus císaře tvoří základní pojící faktor mezi těmito rozličnými osobnostmi, ale podstatné rysy jejich tvorby nutně vycházejí také ze sdílených znalostí a z poptávky zkušených evropských sběratelů po módních tématech a elegantním stylu převládajícího internacionálního manýrismu. Ikonografie Amora a Psýché to dobře ukazuje. Jako námět charakteristický pro rudolfínskou Prahu ho zmínil už Kaufmann ${ }^{6}$ a po něm zejména Thea Vignau-Wilbergová ${ }^{7}$, Sonia Cavicchioli ${ }^{8}$, Mungo Campbell ${ }^{9}$, Susanne H. Kolterová ${ }^{10}$ a Evelyn Reitzová. ${ }^{11}$

Stejně jako v mnoha jiných př́ípadech vycházeli rudolfinští umělci především z italských zdrojů. Malcolm Bull však zdůraznil, že trvalo překvapivě dlouho, než se tento oblíbený ŕímský motiv ujal v Evropě. „Přestože byly od začátku 16. století k dispozici preklady do francouzštiny, španělštiny a němčiny, nevznikala diky nim automaticky vizuální díla. Tento námět se stal jedním z častých témat španělské literatury, ale první dochované malby pocházejí ažz druhé poloviny 17. století. V Německu se motiv neuchytil až do doby Rudolfa II., v Nizozemí se do 17. století objevoval jen sporadicky“. ${ }^{12}$ Podle Bulla za to zčásti mohla popularita literární verze př́běhu, díky které si udržel narativní celistvost, o niž přišla např́iklad řada témat z Ovidia, která se dostala do obecného povědomí primárně v podobě jednotlivých obrazů. Tomu odpovídá fakt, že v Itálii dominoval mýtus o Amorovi a Psýché především velkým nástěnným cyklům ovlivněným nesmírně úspěšnou sérií grafik. V rudolfínském umění ho však představuje několik vybraných scén, jejichž interpretace skrývá obdobná úskalí jako většina ostatních mytologií namalovaných pro Rudolfa II. Dlouhé vyprávění o mnoha překážkách, které potkaly Psýché na její cestě k svatbě s Amorem, se koncentrovalo do ústředních momentů a klíčem k pochopení výběru je pravděpodobně jejich smyslný charakter, nebo možnost alegorického čtení.

$\mathrm{Na}$ otázky, který z těchto faktorů hrál větší roli, jak důležitá byla pro rudolfínce italská literární a vizuální tradice a kde se s ní rozcházeli, nakolik je Amor a Psýché téma typické

5 Thomas DaCosta Kaufmann, L'école de Prague. La peinture a la cour de Rodolphe II, Paris 1985; a zejména rozšířená anglická mutace: The School of Prague. Painting at the court of Rudolf II, Chicago 1988.

6 Kaufmann, The School (pozn. 5), s. 250.

7 Thea Vignau-Wilberg, Grafika a teorie umění kolem roku 1600, in: Eliška Fučíková - James M. Bradburne -Beket Bukovinská - Jaroslava Hausenblasová - Lubomír Konečný - Ivan Muchka - Michal Šroněk (edd.), Rudolf II. a Praha císařský dvưr a rezidenční město jako kulturní a duchovní centrum střední Evropy, Praha - Londýn - Milán 1997, s. 179-188.

8 Sonia Cavicchioli, Le metamorfosi di Psiche. L'iconografia della favola di Apuleio, Venezia 2002, s. $170-182$.

9 Mungo Campbell, Mercury and Psyche - Muller after De Vries, History Today, May 1994, s. 30-35.

10 Susanne H. Kolter, Bartholomaus Spranger „Amor und Psyche“ im Kontext rudolfinischer Hofkunst, Jahrbuch des Landesmuseums für Kunst und Kulturgeschichte Oldenburg 2008, s. 12-21.

11 Evelyn Reitz, Discordia concors. Kulturelle Differenzerfahrung und ästhetische Einheitsbildung in der Prager Kunst um 1600, Berlin 2015, zejména s. 165-167.

12 Malcolm Bull, The Mirror of the Gods. Classical Mythology in Renaissance Art, London 2005, s. 197. 
právě pro Rudolfa II. a jaké změny prodělaly postavy příběhu i podstata jeho vyprávění na konci 16. století, je možné hledat odpovědi zejména díky velkému množství sekundárních zdrojů z různých humanitních oborů. Apuleiovu Zlatému oslu a jeho druhému životu věnovala velkou pozornost celá řada literárních vědců.

V posledním desetiletí vyšly dvě velké přehledové práce, které stopují cestu románu od antiky do renesance. V roce 2008 publikovala v Princeton University Press Julia Haig Gaisserová knihu The Fortunes of Apuleius and the Golden Ass ${ }^{13}$ a tentýž rok vydalo Oxford University Press monografii Roberta H. F. Carvera The Protean Ass. ${ }^{14}$ Dvě podobné a vzájemně se doplňující studie umožňují pochopení recepce antického románu v novověku nejen v Itálii, ale také v Německu, Španělsku a v případě Carvera zejména $\mathrm{v}$ alžbětinské Británii. Součástí kulturní výměny, kterou popisují, byla samozřejmě také rudolfínská Praha.

Zajímavý pohled do vztahů mezi literární a vizuální tradicí v Itálii, Británii i na jiných evropských dvorech přinesla Jane Kingsley-Smithová v knize Cupid in Early Modern Literature and Culture. ${ }^{15} \mathrm{Na}$ př̀klady Zlatého osla a jejich vliv na výtvarné umění se soustředila Mariantonietta Acocella v L'Asino d'oro nel Rinascimento. ${ }^{16}$ Warburgův institut v Londýně uspořádal v roce 2016 konferenci na téma The Afterlife of Apuleius. Samostatnou kapitolu tvoří literatura věnovaná ikonografii Amora a Psýché v renesanci i později. Důležité shrnující práce v poslední době napsaly či editovaly Sonia Cavicchio$\operatorname{li}^{17}$ a Elena Fontanella ${ }^{18}$.

Zmíněné práce samozřejmě představují pouze zlomek z toho, co bylo napsáno o Apuleiově románu, kterému věnovaly soustředěnou kritickou pozornost generace badatelů nejméně od jeho prvního vydání tiskem. Podobně nepřeberné množství informací proto nabízí také literatura, kterou může považovat za primární pro rudolfínské umění, od románu samotného přes jeho rané alegorické interpretace v podání Fulgentia a Martiana Capelly, komentáře od Giovanniho Boccaccia po Filippa Beroalda a nejrůznější převyprávění až po umělecké traktáty a ikonografické manuály.

Dilema, které řeší ikonolog postavený před rozsáhlý soubor textů zabývajících se významy a symbolikou v novověké kultuře, trefně popsal Ernst H. Gombrich. „Nobody who has looked into medieval and Renaissance texts concerned with symbolism can fail to be both impressed and depressed by the learning and ingenuity expended on this task of applying the techniques of exegetics to a vast range of texts, images or events. The temptation is indeed great for the iconologist to emulate this technique and apply it in his turn to the works of art of the past." 19 Ve studii Aims and Limits of Iconology Gombrich zdurraznil rizika, jaká takový př́istup skýtá. Dokladem selhání pod tíhou nesmírného množství materiálu a následnému propadnutí depresím je ostatně také postava Edwarda Casaubona $\mathrm{z}$ úvodní citace.

13 Julia Haig Gaisser, The Fortunes of Apuleius and the „Golden Ass": a study in transmission and reception, Princeton 2008.

14 Carver, The Protean Ass (pozn. 3).

15 Jane Kingsley-Smith, Cupid in Early Modern Literature and Culture, Cambridge 2010.

16 Mariantonietta Acocella, $L$ 'Asino d'oro nel Rinascimento. Dai volgarizzamenti alle raffigurazioni pittoriche, Ravenna 2001.

17 Cavicchioli, Le metamorfosi (pozn. 8).

18 Elena Fontanella (ed.), Amore e Psiche. La favola dell'anima, Milano 2013.

19 Ernst H. Gombrich, Symbolic Images. Studies in the art of the Renaissance II, Oxford 1985, s. 14-15. 
Následující text si neklade za cíl vyčerpávající výklad rudolfínských uměleckých děl inspirovaných Apuleiovým Zlatým oslem ani kompletní soupis jejich dalších možných literárních a ikonografických zdrojů. Především má nastínit předpoklady úspěchu motivů z Apuleiova románu na dvoře Rudolfa II., složitou historii šíření jeho textu od svitku po novověké tisky a kontext, ve kterém antický př́iběh vnímali Rudolfovi současníci.

\section{Uznávané dědictví Apuleiovo}

„Uvědomujete si, jak obrovský význam mèla epocha mezi druhým a třetím stoletím našeho letopočtu? Vưbec ne kvůli okázalé nádheře impéria, na které se už snášel soumrak, ale kvi̊li tomu, co rozkvétalo ve Středomoří. V Řimě pretoriáni podřezávali císaře, kdežto ve Středomoři kvetla doba Apuleiova psaní, Isidiných mystérí, velkého návratu duchovna představovaného neoplatónismem, gnózí... Blažená doba, kdy křestané ještě neměli moc a neposílali kaciře na smrt! Nádherná doba, v niž ve světě vládl nús a blesky extází a obydlovali jej duchové, emanace, démoni a andèlské kohorty!" ${ }^{\prime 20}$ Tak popsal atmosféru druhého století po Kristu, období, kdy vznikl Apuleiův Zlatý osel, Umberto Eco v knize Foucaultovo kyvadlo. Emotivní líčení vložil Eco do úst jedné z postav posedlých zkoumáním okultních věd minulosti a hledáním univerzálního spiknutí. Děj románu se odvíjí ve druhé polovině dvacátého století, ale významnou úlohu v něm mimo jiné hrají také literatura, pověsti i fabulace spojené s rudolfínskou Prahou a okruhem lidí, jako byl například John Dee. Rudolf II. se v populární i odborné literatuře stal jedním z nejtypičtějších představitelů vyznavačů okultních věd. $V$ této roli se ocitl již za svého života a také tehdy mnozí jeho zájmům přič́tali neúspěchy v politice a v životě: „Jeho Veličenstvo císař má zájem jen o čarodějníky, alchymisty, kabalisty a jim podobné. Nelituje žádných nákladů př̀i hledání pokladư všeho druhu, odhalování tajemství a pro nalezení hanebných prostředkü, jak škodit svým neprátelưm... Má též celou knihovnu magických spisů. Neustále se pokouši úplně odstranit Boha, aby mohl v budoucnu sloužit jinému pánu“.21 John Barclay okořenil svůj populární satirický román z let 1605-1607 Euphormionis lusinini satyricon postavou bláznivého thébského vládce Aquilia, samotářského podivína se zájmem o alchymii a erotické obrazy, ve kterém Barclayho čtenáři snadno rozpoznali Rudolfa II. Pravděpodobně se také stal inspirací pro postavu Prospera, kterého v Shakespearově Bouři připraví o vládu nad Milánem jeho bratr Antonio právě kvůli Prosperově př́lišnému zaujetí pro okultní vědy a čáry. ${ }^{22}$

Řada shakespearovských badatelů samozřejmě vidí předobraz Prospera v jiných skutečných osobnostech, od Johna Dee přes anglického krále Jakuba I. až po Shakespeara samotného. Rudolf II. však $\mathrm{v}$ každém př́padě již několik set let naplňuje $\mathrm{v}$ představách mnohých obraz člověka propadlého okultismu a magii. $\mathrm{V}$ podobné roli často figuroval $\mathrm{v}$ literatuře od antiky až po novověk Lucius Apuleius z Madaury, jehož díla jistě nemohla chybět v knihovnách humanistů v okruhu Rudolfa II., ani v jeho vlastních sbír-

20 Umberto Eco, Foucaultovo kyvadlo, Praha 2015, s. 198.

21 Z vídeňské dohody habsburských arcivévodů (1606) dle: Robert J. W. Evans, Rudolf II. a jeho svět, Praha 1997, s. 235.

22 Richard Dutton - Jean E. Howard, A Companion to Shakespeare's Works: The Poems, Problem Comedies, Late Plays, 2007, s. 409. 
kách. ${ }^{23}$ Význam Apuleia v dějinách literatury zdaleka přesáhl jeho pověst kouzelníka, která v určitých obdobích ohrožovala zachování jeho děl následujícím generacím, jindy mu ale bezpochyby dodávala na atraktivitě a mohla ovlivnit i jeho recepci na Rudolfově dvoře. Zlatý osel obsahuje v hojné míře obě oblíbené součásti života Barclayho Aquilia, Rudolfova literárního dvojníka, magii a náměty pro smyslné umění.

Apuleius se narodil kolem roku 125 n. l. v africké části římského impéria. Původem byl Numid’an, psal latinsky a řecky. Podle svých vlastních slov dosáhl slávy jako filosof, sofista a platonik. Za svého života čelil obvinění z čarodějnictví, proti kterému se úspěšně bránil a svou řeč sepsal a publikoval. Kromě jejího textu mu k pověsti antického mága pomohl také Zlatý osel, kterého někteří mylně považovali za autobiografii. ${ }^{24} \mathrm{O}$ této stránce reflexe Apuleiovy povahy vypovídá také vůbec první důvěryhodná zmínka, která se o něm zachovala. Lactanius, ř́mský církevní otec, ho v Institutiones diuinae napsaných mezi lety 313 a 315 zmínil v souvislosti s divy a kouzly. Odpovídal na znepokojivá srovnání Kristových zázraků s nadpřirozenými činy pohanů a popřel, že by šlo o stejnou kategorii. Apuleius společně s Apolloniem a dalšími budou podle něj nevyhnutelně čelit Božímu trestu. ${ }^{25}$ Podobně nepřátelsky referovali o Apuleiovi i další apologeté. ${ }^{26}$

Zejména v bouřlivém období čtvrtého století, kdy se upevňovala pozice křest’anství v římské říši a střídala se období potírání pohanských tradic s pokusy o jejich obnovu, se Apuleiovy spisy jevily zvlášt problematické. Apuleius se tehdy jako jeden z mála literátů objevil na medailích (contorniates), které sloužily pohanské propagandě. ${ }^{27}$ Vliv starého římského státního náboženství spojeného s klasickou mytologií stále klesal. Mnozí křestanští myslitelé vysvětlovali tradiční báje po vzoru Euheméra jako zveličené a zkomolené příběhy obyčejných smrtelníků, čímž zpochybňovali jejich moc. ${ }^{28}$ Velkolepý závěr Apuleiova Zlatého osla však představoval relativně nově importovaný kult bohyně Isidy, který měl společně s Mithrovým mystériem potenciál křestanství skutečně konkurovat.

Debata o významu a charakteru zázraků spojených s Apuleiem, př́ípadně hrdinou jeho románu Luciem, a Kristem se proto tehdy zdála zcela na místě. Zapojil se do ní také sv. Augustin, který studoval v Apuleiově rodném městě Madauře a narážky na Apuleiovo dílo figurují v řadě jeho spisů. V dopisech s Marcellinem ${ }^{29}$ reagoval na stejnou argumentaci jako Lactanius, totiž že Apollonius a Apuleius dokázali stejné nebo dokonce větší divy než Kristus. ${ }^{30}$ Podle Augustina nedosáhl Apuleius dostatečného společenského postavení, což vypovídá o jeho malých schopnostech. Augustin také pochyboval o důvěryhodnosti Apuleiova vyprávění, ale zároveň ho nepovažoval za čistou fikci. Věřil, že

23 Ivo Purš - Hedvika Kuchařová (eds.), Knihovna arcivévody Ferdinanda II. Tyrolského (1529-1595), Praha 2016, kat. 5Co, fol: 590v, č. 54.

24 Maaike Zimmerman, 'Food for Thought' for Readers of Apuleius' The Golden Ass, in: Michael Paschalis - Stelios Panayotakis - Gareth L. Schmeling (eds.), Readers and Writers in the Ancient Novel, Ancient Narrative Supplements 12, 2009, s. 218- 240.

25 Carver, The Protean Ass (pozn. 3), s. 19.

26 Ibidem.

27 Ibidem, s. 15.

28 Jean Seznec, The Survival of the Pagan Gods. The Mythological Tradition and Its Place in Renaissance Humanism and Art, New York 1961, s. 12.

29 Carver, The Protean Ass (pozn. 3), s. 24.

30 „In quibus nihil aliud Dominum, quam alij homines facere potuerunt fecisse vel legisse mentiuntur. Apollonium siquidem suum nobis \& Apuleium, aliosque Magicæ artis homines in medium proferunt, quorum maiora contendunt extitisse miracula." Ibidem. 
i proměna člověka v osla je výjimečně možná díky pưsobení démonů. V De ciuitate dei krátce zmínil Apuleiův román pod názvem De Asino Aureo. Jedná se o nejstarší známé použití tohoto titulu. Verze textu, která se jako jediná dochovala do novověku, nesla pouze název Metamorfózy. Přestože se Augustin o Apuleiových údajných magických schopnostech a o jeho románu vyjadřoval negativně, hrála jeho zmínka o nich podstatnou roli v uchování paměti o existenci Zlatého osla v průběhu středověku. Augustin tak ve výsledku pravděpodobně nechtěně významně přispěl k zachování jeho textu.

Způsob, jakým antické mytologické texty přežily do novověku, se značně lišil. Renesanční malíři a jejich patroni samozřejmě ve většině prrípadů nevěnovali peripetiím jejich osudů pozornost. Řadu př́běhů a témat čerpali pouze zprostředkovaně nejprve ze středověkých encyklopedií a mytografických spisů, později ze specializovaných manuálů, sepsaných právě za tímto účelem. Historie téměř úplného zapomnění a následného znovuobjevení Apuleiova textu ovšem vypovídá mnohé o změnách v mentalitě, které souvisely s fenoménem italské renesance. Od doby, kdy některý z florentských protohumanistů našel rukopis Zlatého osla v knihovně středověkého kláštera, do období vlády Rudolfa II. uplynula více než dvě století. $V$ jejich průběhu se zcela zásadně změnily možnosti šíření textu i obrazu, prŕstup k fikci v literatuře i způsob narace ve výtvarném umění. Podobnou transformací nutně prošla většina ikonografických témat, každý konkrétní případ však má svá specifika, která ovlivnila jeho podobu. Popularita příběhu Amora a Psýché v Rudolfově době souvisí s jeho úspěchem v Rímě, který by nebyl představitelný bez kultury florentského quattrocenta. $Z$ tématu srozumitelného pro několik elitních objednavatelů v Toskánsku se stalo jedno z klíčových vyprávění internacionálního manýrismu. Exkluzivně provedená díla s erotickým nábojem sice zůstala především doménou nejbohatší a nejvzdělanější vrstvy, přesto byl jejich dosah na konci 16. století zejména díky grafice nesrovnatelně větší. Lépe než na jiných ikonografických motivech je na příkladu Zlatého osla možné vypozorovat italské a především římské kořeny umění Rudolfova dvora.

\section{Lovci rukopisů}

Linii šíření námětů z Apuleiova románu můžeme jasně sledovat mimo jiné díky tomu, že necelé století poté, co o něm s naprostou samozřejmostí psal sv. Augustin, dílo zcela zmizelo ze zřetele a na povrch se znovu dostalo až ve 14. století. Na rozdíl od Ovidiových Metamorfóz, nejčastějšího zdroje novověké mytologické ikonografie, nebo například Vergiliových spisů se Zlatý osel nestal součástí středověkého kánonu klasických textů. Příběh Amora a Psýché sice přežíval ve formě převyprávění s filosofickým výkladem od Martiana Capelly v De nuptiis Mercurii et Philologiae a Fulgentiových Mitologiarum libri tres, Apuleiův originální text však zapadl stejně jako povědomí o souvislosti pohádky o Amorovi a Psýché s Luciovou nechtěnou proměnou v osla.

Zlatý osel existoval po dobu několika století v jediném rukopise, který obsahoval zároveň Apuleiovu Floridu a Apologii. Pouze štastnou náhodou proto z Apuleiova nejslavnějšího díla zůstalo víc než jenom odkazy v literatuře. Není zřejmé, proč právě Zlatý osel ušel pozornosti středověkých vzdělanců. Zarážející je zejména jeho absence mezi knihami, které kopírovali učenci z okruhu Karla Velikého. Takzvané karolinské renesanci vděčíme za mnohá starověká díla. Do konce osmého století přežila některá z nich 
ještě v podobě svitků a teprve karolinští písaři je přepsali do kodexů. Touto zásadní transformací prošel Zlatý osel již ve čtvrtém století, kdy jej editoval a opatřil přípisem jistý Sallustius ${ }^{31}$. Jeho verze pravděpodobně náležela do sféry děl spojených s jedním z pohanských obratů ve čtvrtém století namířených proti převládajícímu vlivu křestanství v římské říši. To jistě nepřispělo $\mathrm{k}$ Apuleiově popularitě mezi církevními otci. $\mathrm{Na}$ rozdíl od Vergilia či Ovidia ho také nemohli počítat mezi ctnostné pohany, kteří se narodili před Kristem, a přišli proto o možnost poznat a přistoupit k jeho učení. To však ještě nemusel být důvod k jeho úplnému zavržení, jak dokládá př́íklad Macrobia. Ve středověku platil za autoritu ve filosofii i vědě, přestože stejně jako Apuleius patřil mezi neoplatóniky, kteří se nikdy nestali křestany. ${ }^{32}$ Roli v úpadku zájmu o Apuleiův text tak možná měla také jeho svérázná a bohatá latina, která nemohla sloužit tak snadno za vzor jako např́klad Ovidiovy verše. Skutečně však ohrozil jeho existenci pravděpodobně především potenciálně závadný obsah.

Příběh ztráty, objevu a následné slávy Apuleiova Zlatého osla tak připomíná osud Lucretiovy básně De rerum Natura, který glorifikoval v knize The Swerve: How the World Became Modern Stephen Greenblatt. ${ }^{33}$ Do jádra svého vyprávění postavil úspěšné pátrání Poggia Braccioliniho po starověkých rukopisech. ${ }^{34} \mathrm{~V}$ roce 1417 se Poggiovi, známému humanistovi, písaři u papežské kurie a později florentskému kancléři, podařilo získat slavné, ale po staletí ztracené Lucretiovo dílo. Sám Lucretius byl předtím znám pouze $\mathrm{z}$ odkazů v jiné antické literatuře, např́íklad z Quintiliana. Greenblatt od toho momentu stopoval vliv básně, $v$ níž je mimo jiné popřena existence posmrtného života, na kulturu a vědu počínajícího novověku a do značné míry od ní odvozoval počátek renesance a hledal v ní základ dnešního moderního myšlení. Přestože se může Greenblattova působivá verze událostí zdát v některých aspektech přehnaná, popisuje epizodu důležitou pro definici italské renesance. Uvědomělé hledání antické tradice vnímali jako převratné již jeho samotní aktéři ve 14. a 15. století a vychází z něj i tradiční vymezení tohoto období. Podstatný je moment odstupu, nostalgie po ztracené minulosti ${ }^{35}$ a důvěra v nepřekonanou kvalitu děl erudovaných předků. Apuleiův Zlatý osel sice neobsahoval stejně revoluční myšlenky jako Lucretiovo De rerum natura, rozhodně však zásadně ovlivnil mnohá ikonická díla, na nichž je založena naše představa o renesanci. Několik př́běhů Dekameronu vychází z Luciových dobrodružství a mýtus o Psýché zařadil Boccaccio také do své monumentální encyklopedie Genealogia Deorum Gentilium. Hypnerotomachia Poliphili, mnohovrstevné a jazykově složité dílo ze závěru 15. století, má kořeny hluboko ve Zlatém oslu. Dosah Apuleiova románu samozřejmě dalece přesáhl hranice Itálie. Nej-

31 Carver, The Protean Ass (pozn. 3), s. 14.

32 Ernst Robert Curtius, Evropská literatura a latinský středověk, Praha 1998, s. 4.

33 Stephen Greenblatt, The Swerve. How the World Became Modern, New York 2011.

34 Poggio také našel, přeložil a publikoval Lukiánovu řeckou verzi příběhu o proměně v osla"Ovoc.

35 Erwin Panofsky, Renaissance and Renascences in Western Art, Stockholm 1965, s. 113. „It became instead the object of a passionate nostalgia which found its symbolic expression in the re-emergenceafter fifteen centuries - of that enchanting vision, Arcady. Both medieval renascences, regardless of the differences between the Carolingian renovatio and the "revival of the twelfth century", were free from this nostalgia. Antiquity, like the automobile in our homely simile, was still around, so to speak. The Renaissance came to realize that Pan was dead-that the world of ancient Greece and Rome (...) was lost like Milton's Paradise and capable of being regained only in the spirit. The classical past was looked upon, for the first time, as a totality cut off from the present; and, therefore, as an ideal to be longed for instead of a reality to be both utilized and feared." 
různější motivy z něj se prolínají hrami Williama Shakespeara ${ }^{36}$, parafrázoval ho François Rabelais a pro Erasma Rotterdamského byl vzorem bohatého literárního stylu. ${ }^{37}$ Sehrál zásadní roli v diskuzích o povaze a hodnotě smyšlených narací, které nakonec vedly ke vzniku moderního evropského románu a k tzv. triumfu fikce. ${ }^{38}$ Ernst Hans Gombrich považoval Apuleiův text za předlohu Botticelliho Primavery ${ }^{39}$.

Skutečná historie objevu Zlatého osla není zcela jasná, ale některé její aspekty dosahují dramatických kvalit Poggiova pátrání. V odborné literatuře se připisují zásluhy na jeho nalezení různým vzdělaným lovcům rukopisư ${ }^{40} 14$. století, od Zanobiho da Strada po Boccaccia. ${ }^{41}$ Italští humanisté se aktivně pokoušeli dohledat ztracená díla starověku již od doby, kdy se Petrarkovi podařilo najít klíčové spisy Cicerona, Propertia a významně napomoci k rekonstrukci Liviových Dějin Řima. S cílem získat slávu a obohatit evropskou kulturu i svou vlastní knihovnu objižděli středověká opatství a procházeli jejich katalogy rukopisů.

S těmito úmysly cestoval Giovanni Boccaccio do benediktinského kláštera Monte Cassino. Údajně ho však nalezl v takovém úpadku, že jeho žák Benvenuto da Imola cítil potřebu historku o návštěvě opatství zaznamenat v komentáři k pasáži z Dantovy Božské komedie. Dante v ní ústy sv. Benedikta kritizuje současný stav jeho řádu: „la regola mia rimasa è per danno delle carte. Le mura che soleno esser badia fatte sono spelonche, e le cocolle sacca son piene di farina ria. " ${ }^{2}$ Dantova ostrá slova ale vztáhl Benvento pouze na samotné Monte Cassino, které na vlastní oči poznal jeho učitel. Boccaccia šokovalo, že ho bez okolků ihned pustili do knihovny, kam ho poslali jen gestem a hrubými slovy „je otevřeno": "At ille rigide respondit, ostendens sibi altam scalam: ascende quia aperta est" ${ }^{43}$ Poté, co vystoupal po schodech, spatřil místnosti bez dveř́i, okna porostlá travou, police pokryté prachem a zničené knihy, $\mathrm{z}$ nichž mniši pro peníze vyráběli žaltáře pro školáky a breviáře pro dámy. Boccaccio sestoupal po schodišti se slzami v očích, „dolens et illacrymans recessit", a pravděpodobně také s několika rukopisy v ruce, včetně Apuleiova Zlatého osla, jak se domnívají někteří dnešní badatelé. ${ }^{44}$

Tento takřka divadelní scénář by se vyrovnal Poggiovu senzačnímu nálezu, pokud by byl pravdivý. Benvenuto v něm v souvislosti s Dantem záměrně zdůraznil fenomén stoupání do vyšší sféry, kde však potkalo Boccaccia zklamání. Přizpůsobil tak historku komentované literární předloze. Je však lákavé si představit, že Boccaccio při této př́ležitosti na poslední chvíli zachránil jediný existující exemplář Apuleiových spisů před jistým zánikem. Boccaccio měl zásadní zásluhy na šíření povědomí o Apuleiově textu a dodnes existuje jeho vlastnoruční opis Zlatého osla,${ }^{45}$ ale v jeho objevu ho pravděpodobně přede-

\footnotetext{
J. J. M. Tobin, Shakespeare's Favorite Novel. A Study of The Golden Asse as Prime Source, London 1984

37 Carver, The Protean Ass (pozn. 3), s. 268.

38 Ibidem s. 143-144.

39 Gombrich, Symbolic Images (pozn. 19), s. 52-55.

$40 \mathrm{~V}$ angličtině se běžně používá pojem bookhunters.

41 G. Billanovich, I primi Umanisti e le tradizioni dei classici latini, Fribourg 1953, s. 31; Acocella, L’Asino d'oro (pozn. 16), s. 5.

42 Dle: Carver, The Protean Ass (pozn. 3), s. 108.

43 Ibidem, s. 109.

44 Napŕíklad J. F. D’Amico, The Progress of Renaissance Latin Prose. The Case of Apuleianism, Renaissance Quarterly XXXVII, 1984, s. 364-5: "Apuleius (...) was discovered anew by Boccaccio" Viz Carver, The Protean Ass (pozn. 3), s. 110.

45 Biblioteca Medicea Laurenziana, sig. Laur. 54.32.
} 
hnal již protohumanista Benzo d'Alessandria. Zdá se, že Benzo musel číst, nebo alespoň vidět rukopis Apuleiova díla, protože si po velmi dlouhé době jako první uvědomil, že názvy Zlatý osel a Metamorfózy označují stejnou knihu. ${ }^{46} \mathrm{~Sv}$. Augustin v De ciuitate Dei uvedl titul Zlatý osel, ale nezmínil příběh Amora a Psýché. Fulgentius naopak ve svých Mitologiae citoval jako zdroj mýtu o Psýché Metamorfózy, ale zcela vynechal rámec vyprávění o Luciovi a jeho proměně v osla. ${ }^{47}$

Jisté je, že v průběhu 14. století se Zlatý osel vrátil na literární scénu. Citovali ho a ve svých dílech používali nejvýznamnější humanisté. $\mathrm{V}$ době před vynalezením knihtisku se samozřejmě jednalo pouze o omezený okruh lidí, kteří se vzájemně znali a půjčovali si rukopisy. Prozatím byl tedy jeho vliv limitovaný především na Florencii a blízká města. Ve svých dopisech na něj odkazoval Francesco Petrarca, Coluccio Salutati vlastnil a glosoval osobní kopii.

Giovanni Boccaccio podstatně rozšířil znalost př́iběhu Amora a Psýché, když ho zařadil do svého rozsáhlého latinského díla Genealogia Deorum Gentilium. V ambiciózní encyklopedii, napsané mezi lety 1360 a 1374, se pokusil podrobně popsat celý ŕímský pohanský panteon a složité př́buzenské vztahy mezi jednotlivými bohy. Kapitolu 22 páté knihy věnoval Psýché. Kromě Apuleia, kterého označil za důvěryhodného filosofa („non mediocris auctoritatis“) ${ }^{48}$ čerpal také z Martiana Capelly. Proto na začátku uvedl Psýché jako dceru Apollóna, přestože později v příběhu, ve shodě s Apuleiovou verzí, jde její otec konzultovat Apollónovu věštírnu. Výslednou podobu Genealogia Deorum Gentilium i vznik podobných logických chyb ovlivnily pozdější autorské úpravy. Boccaccio výrazně přepisoval některé části na základě připomínek svých kritiků z řad ostatních humanistů. Charakter provedených oprav a korespondence mezi Boccaciem a Pietrem Piccolo da Monteforte napovídají, že musel rozšírit exegetickou část výkladu na úkor samotného př́běhu. ${ }^{49}$ Genealogia Deorum Gentilium proto obsahuje podrobné shrnutí první části příběhu do chvíle, kdy Amor opustí Psýché. Její strádání a úkoly, které svědomitě plní, Boccaccio nerozepsal a vyprávění v krátkosti uzavřel. O to větší prostor ponechal filosofické interpretaci, kde vysvětluje cestu Psýché jako cestu duše k věčné slávě. Z její lásky se zrodí Rozkoš, Voluptas, nekončící radost a požitek.

Na rozdíl od Fulgentiova vlivného výkladu z přelomu 5. a 6. století, v němž chybí štastný konec, se Boccaccio vrátil k Apuleiově původní optimistické verzi. Přidal k ní silně náboženský křestłanský podtext a upravil vztahy mezi aktéry př́iběhu tak, aby zapadaly do celkového konceptu jeho Geneaologie. ${ }^{50}$ Rozehrál vážnější alegoricky interpretovatelnou notu Apuleiova díla, která převládá pouze v pohádce o Amorovi a Psýché a částečně v poslední, mystické kapitole Zlatého osla. Stejně dobře však dokázal vytěžit i humornou stránku románu, když několik zápletek použil v Dekameronu. Pro výtvarné umění a jeho ikonografii je podstatné, že Boccaccio̊v výklad z Genealogia Deorum Gentilium byl jedním ze základní referenčních bodů také pro pozdější encyklopedie a manuály, jako

46 Oba názvy uvedl ve svém historickém díle Cronica a mundi principio, viz J. R. Berrigan, 'The Prehumanism of Benzo d'Alessandria', Traditio 25, 1969, s. 253-4.

47 Carver, The Protean Ass (pozn. 3), s. 113.

48 Giovanni Boccaccio, Genealogia Deorum Gentilium, 1. 5.

49 Luisa Vertova, Cupid and Psyche in Renaissance Painting before Raphael, Journal of the Warburg and Courtauld Institutes XLII, 1979, s. 104-121, cit, s. 106, poznámka 10.

50 Gaisser, The Fortunes (pozn. 13), s. 113. 
např́klad Le imagini de i dei de gli antichi Vincenza Cartariho, hlavní a dobře př́ístupný zdroj námětů po polovině 16 . století.

\section{V době knihtisku}

Již v průběhu 14. století začínal Apuleiův Zlatý osel patřit k běžnému repertoáru italských humanistů a tento trend pokračoval i v průběhu quattrocenta, kdy se také objevily jeho první novověké ilustrace. $V$ měřítkách doby masové rozšíření však přineslo až jeho první vydání tiskem. Editio princeps připravil a úvodem opatřil Giovanni Andrea de Bussi, biskup Alérie. Vyšlo v Rímě, kolébce italského knihtisku, již v roce 1469. Pravděpodobně kvưli jeho popularitě začal Bussi zamýšlené kompletní vydání Apuleiova díla právě Zlatým oslem. V porovnání se závažnějšími filosofickými pracemi, které měly následovat, šlo také o knihu v lehčím tónu. V předmluvě mimo jiné zdůraznil nezvyklou kvalitu Apuleiova vypravěčského stylu. Podle Bussiho se zdá, že př́iběh nepíše, ale maluje; „non scribere: sed pingere plane historiam uideatur. “51 Částečně tím evokoval Horatiovo ut pictura poesis, koncept blízkosti básní a obrazů zásadní např́klad pro teorii benátské malby v 16. století, ale spojovaný také s díly z Rudolfova okruhu. ${ }^{52} \mathrm{~V}$ tomto případě nešlo o malované básně, ale psané obrazy. Několik pasáží ze Zlatého osla se svým charakterem skutečně blíží ekfrázím, čehož také řada umělců využila. ${ }^{53}$

Zásadní vliv na šíření motivů ze Zlatého osla a povědomí o jeho obsahu měly samozřejmě také překlady a nejrůznější převyprávění ve vernakulárních jazycích. Nejprve ho do italštiny přeložil Matteo Maria Boiardo, následovaly překlady do němčiny, španělštiny i angličtiny.

Díky překladu do italštiny se již na konci 15. století v Mantově těšil Zlatý osel popularitě srovnatelné s medicejskou Florencií. Boiardo ho přeložil pro ferrarského vévodu Ercola d'Este, který si knihu zprvu žárlivě střežil. ${ }^{54}$ Boiardův strýc Niccolò da Correggio však na výslovné přání vévodovy dcery Isabelly d'Este př̌ebásnil příběh Amora a Psýché u př́ležitosti její svatby s Francescem Gonzagou, markrabětem mantovským. Fabula Psiches et Cupidini je navzdory svému latinskému názvu napsaná italsky a Correggio v ní zajímavě pozměnil úhel pohledu známého vyprávění. Jako hlavní hrdina a zároveň vypravěč v ní totiž figuruje sám Amor. Tím, že upozadil roli Psýché, oprostil svou báseň od možných alegorických a filosofických výkladů. Představovala duchaplnou zábavu pro čtenáře či diváky, kteří již znali původní text, jehož obměna pro ně znamenala vítané zpestř̌ení. ${ }^{55}$ Podobné variace mohly dobře sloužit také u př́ležitosti nejrůznějších oslav a festivalů.

51 Dle: Carver, The Protean Ass (pozn. 3), s. 169.

52 Thomas DaCosta Kaufmann, Arcimboldo. Visual Jokes, Natural History, and Still-life Painting, Chicago 2009, s. 76; Eros et poesia. La peinture à la cour de Rodolphe II, Revue de l'art, 1985, s. 29-46, cit. s. 36.

53 Zejména jde o pasáže z pohádky o Amorovi a Psýché, kromě příběhu hlavního páru také o divadelní scénu s Paridovým soudem. Například Tizian však využil také popis sochy z druhé kapitoly (Met II, 4). Sousoší, které spatřil Lucius, hrdina Zlatého osla, v domě své tety představovalo Dianu a smrt Aktaióna. Viz Richard Cocke, Titian the Second Apelles: the Death of Actaeon, Renaissance Studies XIII, No. 3, 1999, s. 303-311, cit. s. 306.

54 Gaisser, The Fortunes (pozn. 13), s. 185.

55 Ibidem, s. 188. 
O přízeň nepřišel Apuleius v Mantově ani v průběhu následujících let a Isabellin syn Federico nechal Giulia Romana v pallazzu Te vymalovat jeden z vůbec nejznámějších nástěnných cyklů s námětem Amora a Psýché. Pro dobu Rudolfa II. je podstatné, že pražský dvůr udržoval intenzivní kontakt s gonzagovskou Mantovou a mezi oběma městy probíhala čilá kulturní výměna. ${ }^{56}$

Dvě nejzásadnější renesanční literární díla, která vzešla ze vzrůstající oblíbenosti Zlatého osla, však vznikla v Benátkách a v Bologni. První z nich, Hypnerotomachia Poliphili, vyšla v roce 1499 a její autor dodnes není s jistotou znám. Komplikovaná romance vypráví snový příběh lásky Polifila k Polii a v celé knize se objevují motivy ze Zlatého osla i záměrné odkazy na Apuleiův román. Elegantně upravený tisk doprovázely rafinované dřevořezy s vyobrazeními klasicizující architektury i figurálních scén, $\mathrm{z}$ nichž některé se staly předlohou pro významná umělecká díla následujících století. ${ }^{57}$

Druhý neobyčejně vlivný prvotisk vyšel v roce 1500 v Bologni, nejstarším univerzitním městě s mezinárodní prestiží. Jednalo se o komentovanou edici Zlatého osla v nevídaně velkém nákladu, který dosahoval pravděpodobně téměř dvou tisíc kusů. K vydání ho připravil Filippo Beroaldo, jehož přednášky na univerzitě přitahovaly stovky studentů, z nichž řada pocházela ze zahraničí. Přicházeli ze Španělska, Francie, ale především ze zemí střední Evropy. Tentokrát mířil Apuleiův Zlatý osel skutečně na světový trh a přispěl k rozšíření italské renesanční kultury do Záalpí. Beroaldo ho věnoval Petru Váradimu, bývalému kancléři Matyáše Korvína. Přestože Beroaldo uvedl v úvodu, že se chystá vydat také další Apuleiova díla, nikdy k tomu nedošlo, což odpovídalo dobovému trendu. Ve středověku byl Apuleius znám především jako filosof, ale po objevu Zlatého osla se zájem postupně stále více přikláněl k jeho literárnímu dílu, díky kterému nakonec znovu dospěl k mezinárodní slávě. Apuleiův román s Beroaldovým komentářem dosáhl mnoha vydání a stal se součástí řady knihoven, včetně těch středoevropských. S jistotou víme, že ho vlastnil např́iklad Ferdinand Tyrolský. 58

V kontextu Rudolfových zájmů je také zajímavé, že Beroaldo se svém komentáři nevěnoval tolik rozboru literárních kvalit Apuleiova díla, ale téměř celou předmluvu i závěr dedikoval jeho pověsti kouzelníka a ústřednímu významu magie ve Zlatém oslovi: „quo plane opere Lucius noster magiam asserere eamque rerum omnium potentissimam ostendere pro uirile parte contenditt " ${ }^{9}$ Tehdejší pojetí magie se však značně lišilo od našeho vnímání a zahrnovalo širší okruh činností a vědění. Její definice se v závislosti na období i autorovi velmi různí. ${ }^{60}$

Podobně jako astrologie, alchymie a okultní vědy obsahovala magie mnohé z toho, co bychom dnes zařadili spíš do kategorie vědy či filosofie. Magií se seriózně zabývali muži jako Pico della Mirandola, Marsilio Ficino, Henricus Cornelius Agrippa nebo Giordano Bruno. Apuleius jako neoplatónik a zároveň známý divotvůrce naplňoval jak naši, tak

56 Elena Venturini (ed.), Le collezioni gonzaga. Il Carteggio tra la corte cesarea e Mantova (1559-1636), Carteggio, Cinisello Balsamo 2002.

57 Anthony Blunt, The Hypnerotomachia Poliphili in 17th Century France, Journal of the Warburg Institute I, No. 2, 1937, s. 117-137.

58 Purš - Kuchařová, Knihovna arcivévody Ferdinanda (pozn. 24), 5CO, fol. 590v, č. 54.

59 Beroaldo, fol. 280v dle: Carver, The Protean Ass (pozn. 3), s. 181.

60 K tématu např́iklad: William R. Newman - Anthony Grafton (edd.), Secrets of Nature Astrology and Alchemy in Early Modern Europe, Cambridge, Mass. 2001; Ioan P. Couliano, Eros and Magic in the Renaissance, Chicago 1987. 
tehdejší představu o mágovi a Beroaldo dokonce napsal, že byl považován za největšího ze všech: „Magorum maximus crederetur" 61

V průběhu 16. století se znalost Zlatého osla a jeho ohlas v literatuře rychle šírily společně s dalšími prvky renesanční kultury Evropou. Zejména př́běh Amora a Psýché si našel své místo mezi ostatními mytologickými alegoriemi a romantickými př́běhy. Díky možnému nábožensko-platonickému výkladu o cestě duše, ale také díky svým narativním kvalitám a především z dủvodu, že jako každé pořádné vypravování končí svatbou, byl oblíbenou součástí slavností a dočkal se řady dramatizací. V Anglii se mezi lety 1557 a 1634 hrály nejméně tři hry na téma Amor a Psýché62 a z Apuleiova Zlatého osla hojně čerpal Shakespeare, Sidney, Spenser i další alžbětinci. Později se z Amora a Psýché stala ústřední mytologická dvojice, kterou pro veřejnou prezentaci svého svazku používali Karel I. a Henrietta Marie. ${ }^{63}$ Když jel lord Buckingham vyzvednout budoucí anglickou královnu do Francie, objednal u Rubense obraz, který měl připomínat tuto událost. Existuje kresba, na které je Henrietta Marie vyobrazena jako Psýché, kterou vynáší na nebesa Buckingham v podobě Merkura, zatímco Karel I. jako Amor klečí před Jupiterem ${ }^{64}$ Stejný námět si předtím opakovaně vybral také Rudolf II., ale Sprangerova ani De Vriesova díla neobsahují takto zřejmé kryptoportréty.

Na rozdíl od stuartovského dvora nemáme bohužel tak podrobné informace k obsahu slavností na Rudolfově dvoře ${ }^{65} \mathrm{Na}$ organizaci ceremoniálů, turnajů, zábav a her se podílela řada $\mathrm{z}$ jeho umělců, $\mathrm{v}$ první řadě Giuseppe Arcimboldo, jehož kresby jsou jedním z nejlepších pramenů $\mathrm{k}$ festivitám Maxmiliána II. a Rudolfa II. Jejich program pomáhali připravit také humanisté, mezi jinými historik Wolfgang Lazius, Paulus Fabritius, Giovanni Baptista Fonteo a Jacopo Strada.$^{66}$ Obsahovaly řadu alegorických a mytologických postav, k jejichž ztvárnění použil Arcimboldo popisy z mnoha antických autorů. ${ }^{67}$

Vysoce rozvinutá literární kultura v Anglii na přelomu 16. a 17. století nemá srovnatelný ekvivalent ve střední Evropě. Alžbětinské divadlo zasáhlo široké vrstvy, od nejvyšších elit státu přes řemeslníky až po nejméně placené skupiny obyvatel. Díky množství referencí a použitých motivů ze Zlatého osla v dramatech Shakespearovy doby tak Angličané zprostředkovaně poznali také Apuleia, jehož román ještě před necelým stoletím patřil do intelektuální výbavy hrstky italských humanistů a jejich mecenášn. Rudolfinská literatura naproti tomu zůstala limitovaná převážně na nejvzdělanější část populace, omezený okruh lidí, který žil v úzkém kontaktu se dvorem. Naprostá většina krásné, filosofické i vědecké literatury vznikala nadále v latině, protože postavení národních jazyků ve stř̌ední Evropě bylo výrazně slabší než v Itálii, Británii nebo Francii. Podle Roberta J. W. Evanse byla podstata rudolfínské humanistické kultury „elitářská, ba ezoterická, hluboce spjatá s hieratickou kulturou, na jejímž vrcholu stál filosof-císar̆ a jejiž stupně se měřily podle dvorských ctností a privilegií ducha “ ${ }^{68}$ Část novolatinské poezie, za kterou Rudolf uděloval básníků titul laureatus, měla př́ležitostný, efemérní charakter a brzy upadla do

61 Carver, The Protean Ass (pozn. 3), s. 176.

62 Kingsley-Smith, Cupid (pozn. 15), s. 170.

${ }^{63}$ Kingsley-Smith, Cupid (pozn. 15), s. 173.

${ }^{64}$ Ibidem, s. 173.

65 Evans, Rudolf II. (pozn. 22), s. 201.

${ }^{66}$ Kaufmann, Arcimboldo (pozn. 53), s. 76-78.

67 Ibidem, s. 87.

68 Evans, Rudolf II. (pozn. 22), s. 180. 
zapomnění. Podobně jako ze slavností a z děl s nimi spojených po ní zůstala spíš pouze stopa $\mathrm{v}$ jiných pramenech.

Sofistikovaná výtvarná díla Rudolfova dvora sice patřila stejně omezenému obecenstvu, ale jejich kvalita a význam v tomto případě naopak značně převyšovaly evropský průměr. Zejména díky grafikám mohla i elegantní kabinetní díla, určená pro soukromou potřebu císaře nebo některého z jeho dvořanů, ovlivnit evropské malířství. Ve vizuální kultuře Rudolfovy doby je proto také snadnější vysledovat vliv Apuleiova díla. Z části mohl být přímý, protože Zlatý osel a jeho komentované edice nechyběly v dobových středoevropských knihovnách, ale pravděpodobně častěji jako zprostředkovatel působila italská umělecká scéna a přenos řady námětů probíhal skrze vizuální média. Právě pro ně však hrál zásadní roli renesanční druhý život Zlatého osla. Jeho fenomenální úspěch v Ř́mě a na severoitalských dvorech v první polovině 16 . století významně ovlivnil rudolfínskou malbu na přelomu dalšího století.

Apuleiův Zlatý osel patří společně s díly Lúkiana a Lucretia k nejdůležitějším antickým knihám, které se po staletích zapomnění objevily na konci středověku či počátku renesance, epochy, již do značné míry definovaly. Toto pojetí odpovídá staršímu, burckhardtovskému vnímání přelomu středověku a novověku, způsobu, jakým svou dobu popsali sami italští humanisté a později také Giorgio Vasari. Jules Michelet pro ni použil v roce 1855 v knize Histoire de France pojem znovuzrození. Dnešní historiografická teorie často směřuje ke zpochybnění zavedených stereotypů a zdůraznění mnohdy protichůdných, ale stejně důležitých tendencí v dějinách umění a jejich nelineárního vývoje. ${ }^{69}$ Přesto má právě v prŕípadě některých ikonických děl tradiční vyprávění smysl. Stephen Greenblatt napsal historii moderního světa ve světle Lucretiova De Rerum Natura a Robert H. F. Carver v techničtější, ale neméně podnětné studii zařadil Apuleiův román Zlatý osel do dějin vývoje evropské autonomní krásné literatury jako dílo zásadní pro dominantní roli fikce. Citoval mimo jiné Miguela de Cervantese. Ten popsal ústy kanovníka v Donu Quijotovi de la Mancha milétské povídky, jádro Apuleiova románu, jako nesouvislé povídačky, „které žádného jiného účelu nemají, než baviti, beze všeho poučení, opak mravných povídek, které i baví i poučujou. ${ }^{70 " ~ S a ́ m ~ o v s ̌ e m ~ z e ~ Z l a t e ́ h o ~ o s l a ~}$ samozřejmě hojně čerpal. Cervantesovo dědictví, ${ }^{71}$ dědictví evropského románu, tak do určité míry patří také Apuleiovi.

Př́stup $\mathrm{k}$ naraci a jejímu účelu i význam humoru se proměňoval také ve vizuální kultuře. Termíny, které používá literární věda a dějiny umění, se často prolínají. Thomas DaCosta Kaufmann v souvislosti s ikonografií rudolfinského malírství často mluví o rétorice $^{72}$ a pro charakter Arcimboldových kompozic použil termín „serious joke “73, který částečně vychází z textů Erasma Rotterdamského. Právě Lúkianos a Apuleius, dva autoři spojovaní s konceptem joco-serium, byly zase jedním ze stěžejních zdrojů Erasma. ${ }^{74}$

69 Například William Caferro, Contesting the Renaissance, Oxford 2011, s. 17; Evelyn Welch, Presentism and the Renaissance and Early Modern Historian, Past \& Present, Volume 234, Issue 1, 2017, s. 245253.

70 Miguela de Cervantes de Saavedra Don Quijote de la Mancha, překlad J. B. Pichl, Praha 1866, s. 351.

71 Milan Kundera, Zneuznávané dédictví Cervantesovo, Brno 2005.

72 Kaufmann, The School (pozn. 5) s. 55-60, Kaufmann, Arcimboldo (pozn. 52), s. 12.

73 Kaufmann, Arcimboldo (pozn. 53), zejména s. 91 a dále.

74 Carver, The Protean Ass (pozn. 3), s. 297. 
Postava Apuleia tak rezonovala v Rudolfově době v mnoha ohledech. Z Apuleia mága raného křestanství se stal v průběhu středověku Apuleius filosof a v novověku čím dál tím více spisovatel. Více tváŕí mu však zůstalo i nadále. V několika podobách je ostatně zobrazen již v iluminovaném rukopise ze 14. století. Nejprve jako filosof, na dalších foliích jako spisovatel, kouzelník a nakonec také jako osel. ${ }^{75}$

\section{Vizuální kultura}

Apuleiův Zlatý osel sehrál významnou roli v historii novověké a moderní literatury. Na počátku jeho úspěchu stál pravděpodobně štastný objev Benza d’Alessandria, díky kterému se v dalších staletích těšil literární slávě. Jedním z jejích projevů byla řada citací, referencí a parafrází v dílech jiných významných autorů. Tento přirozený způsob šíření informací, částí textu, běžných citací i záměrných narážek určených pro zasvěcené provázel psanou kulturu již od jejích počátků. S přechodem od svitků ke kodexům, které umožňovaly snadnější procházení textu, a později s rozvojem knihtisku však získal nové rozměry. Zlatý osel patřil k prvním knihám vytištěným v Římě a Apuleius byl náhle ještě mnohem dostupnější a známější než $\mathrm{v}$ době, kdy měl jeho portrét na medailích sloužit pohanské propagandě.

Tak jako knihtisk nevratně změnil evropskou literaturu, ovlivnil vynález grafických technik také vizuální kulturu. Nový způsob šíření kompozic se nutně promítl do ikonografie téměř každého námětu a zároveň umožnil odlišný způsob využívání kopírování, který se mnohem více blížil právě citacím v literatuře. ${ }^{76} \mathrm{Za}$ mezník se v tomto ohledu dá označit Raffaelova tvorba a jeho nesmírně úspěšné spojení s Marcantoniem Raimondim. Do tohoto přelomového období spadá řada grafik s tématem Amora a Psýché, jejichž význam je pro šírení povědomí o Zlatém oslu srovnatelný s edicemi textu. Vizuální kultura také představovala podstatný zdroj rudolfínské ikonografie a nejméně v př́padě Amora a Psýché to byla zejména římská malba a její reprodukce. Sofistikovaná manýristická díla Rudolfova dvora závisejí na schopnosti jejich obecenstva rozpoznat reference a orientovat se v právě vznikajícím uměleckém světě v moderním slova smyslu. ${ }^{77}$ Pro pochopení této kultury je nutné poznat římské a částečně také benátské prostředí předchozích desetiletí. „Malířská kvalita“ Apuleiovy prózy, kterou zdůraznil Giovanni Andrea de Bussi $\mathrm{v}$ editio princeps, však inspirovala umělce již o století dříve.

Poprvé se př́běh Amora a Psýché samostatně objevil mezi náměty na florentských malovaných truhlicích v 15 . století, takzvaných cassoni. Jako důležitou součást svatební výbavy si je pořizovali členové nejvlivnějších rodin, ale i bohatší řemeslníci. Jejich boky i víka pokrývaly motivy ze Starého zákona, italských novel a římské mytologie i historie. Vủbec poprvé od konce starověku na nich byly zobrazeny např́iklad některé výjevy z Homéra či Vergilia. Stylem malby odpovídaly ještě pozdní gotice, jejich ikonografie však mnohdy reflektovala současnou humanistickou kulturu. V první polovině quattrocenta jim dominovala témata ze středověkých romancí, lidové literatury, ale také Boccacciova Dekameronu, zatímco později se zájem přesunul více k antickým bájím a římské histo-

75 Biblioteca Apostolica Vaticana, Vat. lat.2193.

76 Alexander Nagel - Christopher S. Wood, Anachronic Renaissance, New York 2010, s. 356.

77 Alexander Nagel, Merchant of Venice, Art Forum, January 2007, s. 109. 
rii. ${ }^{78}$ Apuleiovo vyprávění končí svatbou Amora a Psýché, což z něj dělá ideální námět pro svatební truhlici. Do dnešní doby se dochovala řada desek s tímto motivem, $\mathrm{z}$ nichž některé evidentně vycházejí z Boccacciovy verze v Genealogia Deorum Gentilium, ale jsou doplněny podle Apuleiova originálního textu. ${ }^{79}$

Impulz k prvním ilustracím Zlatého osla vzešel pravděpodobně z prostředí kolem rodiny Medici. Jedny z nejstarších desek s př́iběhem Psýché tvořily původně pár truhlic, které nesly medicejský znak. Jistě není náhoda, že to byli také oni, kdo vlastnil rukopis s Apuleiovými spisy. Generace Medicejských mezi lety 1425 a 1490 objednaly nejméně tři opisy Apuleiova kompletního díla. ${ }^{80}$ Vyobrazení Amora a Psýché tak v 15. století náležela velmi limitovanému vzdělanému obecenstvu a vděčila za svou popularitu na konci 15. století mimo jiné Cosimově platónské akademii ve vile Careggi a filosofii Marsilia Ficina. ${ }^{81}$

Značná část ikonografie florentských cassoni vycházela z vysoce specializované kultury a nesla originální znaky, z nichž se řada objevila pouze ve Florencii a nejbližších městech. Také časově byla omezena pouze na několik nesmírně plodných desetiletí.

Vzhledem k tomu, že se jednalo o takto specifickou kulturu, nedocházelo prozatím k významnějšímu šíření ikonografických námětů. Podobně plodné prostředí pro Apuleiův román představovala renesanční Ferrara, kde vznikl Boiardův překlad do italštiny a Corregiova báseň pro Isabellu d'Este. Její otec Ercole si nechal v paláci Belriguardo vymalovat možná vůbec první monumentální nástěnný cyklus s Amorem a Psýché, který se však do dnešní doby nedochoval a známe ho pouze z popisu. ${ }^{82}$

Nehynoucí slávu však přinesla Amorovi a Psýché až další velká zakázka. V roce 1519, krátce před svatbou se svou dlouholetou milenkou Francescou Ordeaschi, si nechal sienský bankéř Agostino Chigi vymalovat lodžii vily na břehu Tibery. Pravděpodobně na počest své ženy, která pocházela z výrazně nižší společenské vrstvy než on, zvolil př́iběh Psýché, smrtelné dívky povýšené mezi bohy. Tímto důležitým úkolem pověřil Raffaela a jeho pomocníky, protože pro něj již pracovali v jiných místnostech domu. Zajistil tím Apuleiovu Zlatému oslu výsadní postavení ve vizuální kultuře následujících století. Svou roli v tom sehrál zejména cyklus grafik v Raffaelově stylu a také věhlas vily jako místa, kam se chodí školit mladí umělci z celé Evropy.

\section{Grafika - cesta z Ríma}

Kolem roku 1530 přišel do Říma Michiel Coxcie, mladý malír z Mechelenu v Brabantsku. ${ }^{83} \mathrm{~V}$ té době začínalo být běžné, že ambicióznější malíři ze Záalpí i jiných částí Evropy dokončovali svá studia právě v Římě. Coxcie patřil mezi ty nejúspěšnější a rychle získal důležité zakázky, včetně fresky Zmrtvýchvstání Krista ve staré svatopetrské bazilice. Do-

\footnotetext{
78 Jacqueline Marie Musacchio, Art, Marriage, \& Family in the Florentine Renaissance Palace, New Haven 2008, s. 149.

79 Vertova (pozn. 50).

80 Gaisser, The Fortunes (pozn. 13), s. 150.

81 Vertova (pozn. 50), s. 115.

82 Vertova (pozn. 50), s. 119; Gaisser, The Fortunes (pozn. 13), s. 188; Acocella, L'Asino d'oro (pozn. 16), s. 110-111.

83 Koenraad Jonckheere (ed.), Michiel Coxcie 1499-1592 and the giants of his age, London 2013.
} 
dnes se dochovala jedna ze dvou kaplí, které maloval v Santa Maria dell' Anima, kostele německé komunity. Přes zjevné úspěchy Coxcie pravděpodobně čelil v tomto uměleckém odvětví velké konkurenci. Nejlepší práci většinou dostávali italští malíři jako Jacopino del Conte, Pirro Ligorio, Battista Franco, Francesco Salviati a Daniele da Volterra. Po svém návratu $\mathrm{z}$ Janova $\mathrm{v}$ roce 1537 navíc ovládl římský trh jeden $\mathrm{z}$ nejvýznamnějších dědiců Raffaelovy dílny Perino del Vaga, lepšímu postavení než on se těšil už pouze Michelangelo. Velký potenciál pro Michiela Coxcieho však skýtal právě se rozvíjející obchod s grafikami.

Toho využil také jiný cizinec v Ř́mě, Španěl Antonio Salamanca. Nejprve se živil prodejem knih na Campo de’ Fiori, ale rychle pochopil, jak využít možností nového média a vzrůstajícího zájmu o antické výtvarné i literární památky a ve druhé polovině dvacátých let začal tisknout. Mezi jeho nejúspěšnější díla patří cyklus 32 grafik s př́iběhem Amora a Psýché ze Zlatého osla. [1] Tisky nesou pouze jména vydavatele a rytců Mistra B s kostkou ${ }^{84}$ a Agostina Veneziana, za jejich autora ale Vasari označil Michiela Coxcieho. Ten se ke konci svého římského pobytu intenzivně věnoval kreslení předloh a kromě Amora a Psýché vytvořil také cyklus Jupiterových lásek. Salamanca využil Coxcieho schopnosti napodobit tehdy velmi žádané stile raffaellecso a možná záměrně neuvedl jméno inventora, aby se zdálo, že je jím sám Raffael. ${ }^{85}$ Tomu připsal rytiny už Giovani Battista Armenini a někteří uvažují o jeho autorství dodnes. ${ }^{86} \mathrm{O}$ ekonomickém potenciálu Raffaelových vzorů vypovídá také Vasariho tvrzení, že po vyplenění Ríma jediný „Il Baviera, che teneva le stampe di Raffaello, non aveva perso molto".87

Ve svém návrhu mohl Coxcie vyjít ze dvou monumentálních cyklů nástěnných maleb. Podle některých teorií měl k dispozici Raffaelovy nerealizované kresby pro vilu Agostina Chigiho $^{88}$ a znal pravděpodobně také výzdobu Giulia Romana v mantovském sídle Federica II. Gonzagy. Velká část následujících zakázek se stejnou tematikou ale naopak kopíruje Coxcieho jasné a jednoduše reprodukovatelné kompozice. Perino del Vaga použil stejné vzory už v Janově v paláci Doria a později v místnostech Andělského hradu, které vymaloval pro papeže Pavla III. Farneseho. [8] Ze Salamancových grafik čerpal také autor maleb v ř́mském paláci Capodiferro, pravděpodobně Girolamo Siciolante. Mezi jeho pomocníky figuroval nezvykle velký počet cizinců, zejména Vlámů, Španělů a Francouzů. ${ }^{89}$ Ti mohli znalost Coxcieho předloh později šiřit za hranicemi Itálie. Umělci, kteří přijeli do Říma rozširrit své vzdělání a zkušenosti, také tvořili významnou skupinu zákazníků pro trh s grafikami. Z mnoha dalších cyklů lze jmenovat palazzo Orsini v Braccianu, kde maloval Taddeo Zuccari, nebo palazzo Pallavicino v Janově s freskami od Ottavia Semina. ${ }^{90}$

První samostatná série grafik podle Apuleiova Zlatého osla nezávislá na edici textu tedy vznikla jako dobrý obchodní tah v době, kdy etablující se médium tisku procházelo radikálními proměnami. Podle Livie Montagnoli stojí na pomezí dvou období, zlaté

\footnotetext{
$84 \mathrm{~V}$ italštině se pro označení anonymního rytce používá jméno Maestro del Dado.

85 Echard Leuschner, The Young Talent in Italy, in: Jonchheer (pozn. 84), s. 62.

86 Florian Weiland-Pollerberg, Amor und Psyche in der Renaissance. Medienspezifisches Erzahlen im Bild, Petersberg 2004, s. 118.

87 Giorgio Vasari, Vita di Perino del Vaga, in: Opere di Giorgio Vasari. Pittore e Architetto Aretino. Volume II, Firenze 1822, s. 724.

88 Weiland-Pollerberg, Amor und Psyche (pozn. 86), s. 118.

89 Nicole Dacos, Viaggio a Roma. I pittori europei nel,500, Milano 2012.

90 Claudia Cieri Via, L' arte delle metamorfosi : decorazioni mitologiche nel Cinquecento. Roma 2003, s. 27.
} 
epochy Raffaelovy tvorby a fáze, kdy se kodifikoval repertoár snadno reprodukovatelných kompozic. „Se fino alla metà del secolo le immagini mitologiche appariono ricche di valenze simboliche, le stampe succesive sembrano ripetere stancamente il repertorio precedente. "91 Tento proces badatelka spojila s požadavky tridentského koncilu na jednotu obrazu a jeho významu a s pokusy o větší systemizaci, jejímž produktem byly podle ní př́ručky jako Cartariho Immagini degli dei antichi z roku 1556 a Iconologia Cesare Ripy z roku 1593. Výsledek tohoto „unaveného“ opakování stále stejných motivů může představovat např́klad i řada realizací 17. století ve střední Evropě, které přesně vycházejí z grafických cyklů podle Ovidiových Metamorfóz či právě z Coxcieho Amora a Psýché. V Čechách použil jeho předlohy po více než sto letech od jejich vytvoření například Carpoforo Tencalla, když maloval v Náměšti nad Oslavou. ${ }^{92}$

Grafické techniky však umožnily také jiný, mnohem originálnější způsob kopírování, který našel své místo v umění Rudolfova dvora. V knize Anachronic Renaissance, v kapitole věnované Raffaelově Athénské škole, Christopher S. Wood a Alexandr Nagel zdůraznili proměnu vizuální kultury po masovém uplatnění reprodukce obrazů. Poprvé v historii je podle nich možné chápat malby podobně jako text. Od této chvíle je nutné rozlišovat mezi kopiemi ve smyslu neinvenčních děl nebo devočních předmětů, v jejichž př́padě sledovatelná řada vzorů legitimizuje jejich posvátnost, a mezi záměrnými citacemi a narážkami. Hypoteticky by se tak významně lišilo např́klad spojení mezi Zmrtvýchvstáním Krista ze Sansepolcro od Piera della Francesca a původním hlavním oltářem z katedrály od Niccoly di Segna z roku 1340 od podobně doslovného převedení starší kompozice u Raffaela po jeho příchodu do Říma. Zatímco u Piera jde o pochopitelnou posloupnost v náboženském, posvátném duchu, Raffaela bychom v takovém př́ípadě již považovali za obyčejného kopistu, pokud bychom se to nerozhodli číst jako citaci. ${ }^{93}$ Pro Wooda a Nagela je zásadní otázka času a odstupu. „Citation secures the presence of the past in the present by an authorial decision, rather than by direct work-to-work survival. Citation symbolizes the capacity of the author to make decisions. "94

Díky dostupným konvolutům grafik podle antických i moderních děl rozuměli citacím částí kompozic i jednotlivých figur také objednavatelé, kteří se je naučili vyhledávat a oceňovat. ${ }^{95}$ Fenomén více či méně sofistikovaných odkazů se tak rychle rozširril v evropské malbě, které dominoval nejméně do 19. století. Podle Wooda a Nagela si toho byl vědom např́klad Aby Warburg a kvůli tomuto přesycení referencemi přestal sledovat výskyt formulí patosu v období po roce $1500 .{ }^{96}$

Hlavní rudolfínští figuralisté, Bartholomeus Spranger, Hans von Aachen i Josef Heintz, měli osobní zkušenost s italskou a zejména římskou důmyslnou malířskou kulturou a jejich mecenáše Rudolfa II. považoval za jednoho z nejpozoruhodnějších a nejnáročnějších sběratelů a objednavatelů umění své doby již Karel van Mander. ${ }^{97} \mathrm{~V}$ jejich tvorbě se tak

91 Livia Montagnoli, La serie del Maestro del Dado: trentadue stampe per illustrare la favola di Amore e Psiche, in: Fontanella (ed.), Amore e Psiche (pozn. 18), s. 74.

92 Martin Mádl (ed.), Tencalla II. Barokní nástěnná malba v českých zemích, Praha 2013, s. 19-92.

93 Nagel-Wood, Anachronic Renaissance (pozn. 77), s. 357.

94 Ibidem, s. 357.

95 Nagel, Merchant (pozn. 78), s. 19.

96 Nagel-Wood, Anachronic Renaissance (pozn. 77), s. 357.

97 Evans, Rudolf II. (pozn. 22), s. 197. 
otevřel velký prostor pro citace antických i moderních děl. Na příkladu témat za Zlatého osla se dá dobře demonstrovat, jak originálně uměli využít vizuální tradici.

Příběh ze Zlatého osla se těšil obzvláštnímu úspěchu na trhu s grafikami. Do cyklu Lásek bohů je zahrnul Gian Giacomo Caraglio [9], malby podle Coxcieho zdobily řadu italských paláců a Raffaelovy návrhy vycházely tiskem ještě za jeho života. Amor a Psýché ale vstoupili do života mnoha mladých umělců ještě jinou cestou.

\title{
Fenomén Farnesina - cesta do Ríma
}

\author{
Desio d'imparar lo va adducendo \\ Su l'aggiacciate pietre, ch'à se stesso \\ Fura molti anni non se n'accorgendo. \\ Taddeo Zuccaro alle loggie di Agustin Chigi. \\ Vi dorme, e studia la notte, e vi s'amala..$^{98}$
}

Taddeo Zuccaro zemřel v den svých 37. narozenin, tedy ve stejném věku jako Raffael. Jeho mladší bratr Federico ho nechal pochovat v blízkosti věhlasného mistra v Pantheonu. Taddeův náhrobek dokonce parafrázuje Raffaelův působivý epitaf s textem „Ille hic est Raffael, timuit quo sospite vinci, rerum magna parens et moriente mori. “ Federico však zašel v oslavě svého bratra ještě dál. $\mathrm{V}$ devadesátých letech nakreslil sérii dvaceti kreseb z raného života Taddea Zuccara určenou pravděpodobně jako předlohu pro nástěnné malby. Tehdy Taddeo ještě zdaleka nekonkuroval „matce př́rodě“, ale naopak strádal jako mnoho jiných umělců, kteří právě přicestovali do Říma. Na jedné z nejpůsobivějších kreseb cyklu ho Federico zobrazil, jak při měsíčním světle kopíruje Raffaelovy fresky v lodžii vily Agostina Chigiho. Ilustroval fázi Taddeova života, kdy intenzivně studoval Raffaelovy práce a zároveň neměl kde spát, takže často ve vile i strávil noc. Studená kamenná podlaha údajně vážně ohrozila Taddeovo zdraví, na což poukazuje citovaný komentář ke kresbě a referuje o tom i Vasari.

Unikátní série kreseb vypovídá mnoho o výchově i útrapách nejen Taddea, ale také řady jiných mladých umělců, kteří přišli do Říma dokončit vzdělání a hledat práci. Mezi sdílenou zkušenost několika generací patřila téměř povinná návštěva Raffaelovy lodžie s výjevy ze Zlatého osla. Zdá se, že po smrti Agostina Chigiho i poté, co ji koupil kardinál Alessandro Farnese, byla vila často přístupná a stala se jedním z center římského uměleckého života. Mířili tam samozřejmě i malíři ze Záalpí a s velkou pravděpodobností ji na vlastní oči poznali i Bartholomeus Spranger ${ }^{99}$, který pracoval pro rodinu Farnese, Josef Heintz, jehož kresby podle putti z Farnesiny jsou dnes uloženy v Albertině, ${ }^{100}$ a další rudolfínští figuralisté.

Kopírování ve Farnesině vstoupilo právem do legend o kariérách slavných malíruo̊. Bellori v životopise Federica Barocciho vyprávěl historku, jak v něm Giovanni da Udine rozpoznal talent srovnatelný s Raffaelem. Federico, původem z Urbina, stejně jako obdi-

\footnotetext{
${ }^{98}$ Doprovodný text u kresby, viz Julian Brooks, Taddeo and Federico Zuccaro. Artist-brothers in Renaissance Rome, Los Angeles 2007, s. 32.

${ }^{99}$ Reitz, Discordia (pozn. 11), s. 166.

${ }^{100}$ Albertina, inv. 458.
} 
vovaný Raffael, v pomyslné soutěži překonal další dva malí̌re, cizince, kteří chodili kreslit do Farnesiny. ${ }^{101}$

Belloriho popis evokuje obraz Farnesiny jako živého místa, kde se potkávali a vyměňovali si zkušenosti umělci z různých koutů Evropy. Bohatí dobře oblečení cizinci, které doprovází sluha, aby jim ostřil tužky, a jimž ostatní uvolňují nejlepší místa v Raffaelově lodžii, ale patrně zdaleka neodpovídali běžné realitě. Také mezi ostatními, chudšími návštěvníky vily jistě často zněly jiné jazyky než italština.

Umělci ze zahraničí, zejména z německých zemí, Flander a Nizozemí, takzvaní oltremontani, tvořili v Ř́mě 16. století fenomén, který ovlivnil nejen podobu renesančního a manýristického umění za Alpami, ale obohatil také římské prostředí. ${ }^{102}$ Nicol Dacos zdůraznila v knize Viaggio a Roma radikální charakter proměn, který přinesla v 16 . století tato kulturní výměna. ${ }^{103}$

Řada náročných nástěnných cyklů v kostelích i palácích tehdy vyžadovala velké množství pracovní síly a vedla ke vzniku efektivních mezinárodních dílen. Stěny mnoha římských budov tak pokrývají malby, na kterých se dá rozeznat zarážející množství různých rukou a stylů. Kontakty a zakázky získávali nově příchozí díky dobře propojené síti obchodníků s uměním, která jim navíc skýtala alespoň základní zázemí v cizím dynamickém světě. ${ }^{104}$ Mezi takové podnikatele ${ }^{105}$ patřil v Rímě například Anthonis Santvoort, u něhož bydlel také Hans von Aachen. V jeho domě u fontány di Trevi a později ve Via di Ripetta se shromaždovali různorodí malíři, kteří nevytvářeli žádnou jednotnou školu. Jejich styl kolísal od sofistikovaných manýristických kompozic ve stylu Bartholomea Sprangera až po klasicizující antimanýrismus Federica Zuccariho. V kruzích kolem Santvoorta byl také velmi vlivný způsob kresby Hanse Speckaerta.

Vila Farnesina patřila vedle těchto ubytoven a dílen $\mathrm{k}$ dalším místům, kde probíhala intenzivní výměna zkušeností, motivů i stylů. Ikonická lodžie tak ovlivnila popularitu Amora a Psýché podobně jako rozšířené cykly grafiky. Bartholomeus Spranger přišel

${ }^{101}$ Giovanni Pietro Bellori: Le vite de pittori, scultori ed architetti moderni, Roma 1728, s. 100. „Non sarà superfluo il riferire quello che egli stesso raccontava, come disegnando nella loggia de' Chigi, vi capitò Giovanni da Udine all'ora tornato a Roma, il quale amando gli studiosi del suo maestro Raffaele, rivedeva li disegni, ed animava li giovini con buoni ammaestramenti. Sicche fermatosi a riguardare Federico, e lodando il modo, e la diligenza l'interrogò della patria, e della sua conditione, ma nell'udir solo che egli era d'Urbino, l'abbracciò, e lo baciò tutto commosso dalla memoria del suo caro maestro, ringratiando Dio di vedere uno in cui risorgesse la gloria d'Urbino: questa attione fù avvertita da ciascuno; e Federico si rese riguardevole appresso gli altri. Frequentavano il medesimo luogo due giovini forastieri, li quali però venendo à disegnare si conducevano il paggio per aguzzare il lapis, portandosi con pompa d'habiti, onde ciascuno li honorava, e cedeva loro il luogo. Per questo Federico ch'era nuovo in Roma credendosi che disegnassero à maraviglia, non ardiva accostarsi à vedere i loro disegni; se non che trasportato dalla voglia, tanto si avanzò à poco à poco, che pose gli occhi su la cartella, e restò deluso dal poco saper loro."

${ }^{102} \mathrm{~K}$ tomuto fenoménu zejména Nicole Dacos, např. Viaggio a Roma (pozn. 90), Fiamminghi a Roma 1508 - 1608, Roma 1999.

${ }^{103}$ Dacos, Viaggio a Roma (pozn. 90), s. 145. „Fino alla fine dell'Ottocento, prima dell' 'emergere delle avanguardie, gli artisti seguivano in genere un percorso più lineare, tutto interno alla stessa cultura. È raro assistere a una traversata paragonabile a quella affrontata dai pittori viaggiatori del Cinquecento, che implicava una rottura radicale nel repertorio come nel formato, nell' iconografia come nella composizione e nella tecnica, ossi un totale sconvolgimento delle loro arte“.

${ }^{104}$ Bernard Aikema, Hans von Aachen in Italy. A reappraisal, in: Lubomír Konečný - Štěpán Vácha, Hans von Aachen in kontext, Praha 2012, s. 17-27; Isabella di Lenardo, The oltramontani Network in Venice, in: Konečný - Vácha, ibidem, s. 28-37; Eliška Fučíková, Hans Speckaert, Hans von Aachen and Artists around Them, in: Konečný - Vácha, ibidem, s. 38-44.

${ }^{105}$ Aikema používá slovo entrepreneur. 
do Ríma v roce 1566, tentýž rok zemřel a byl v Pantheonu pochován Taddeo Zuccaro. Pro Nicole Dacos představovalo toto datum mezník v dějinách římského malírství, kterým začala kapitolu o čtvrté generaci cizinců přicházejících do věčného města. ${ }^{106}$ Kromě Bartholomea Sprangera do ní patřili také Hans von Aachen a Josef Heintz. Do Ríma se tehdy s Bertojou a Raffaellem da Reggio vrátila móda Parmigianinova stylu, zásadní realizaci šedesátých let představovala výzdoba vily Alessandra Farnese v Caprarole a mezi vlivné malíře aktivní v Rímě se dostal Jacopo Zucchi. ${ }^{107}$ Následující desetiletí představují klíčová léta pro vznik internacionálního manýrismu a stylu Rudolfova dvora. Nejprve Spranger a později i ostatní budoucí přední rudolfínští figuralisté do tohoto prostředí patřili a reflektovali jeho specifický a rychle se proměňující sloh. Hans von Aachen přicestoval do Ríma asi deset let po Sprangerovi a za dalších deset let se k němu přidal Josef Heintz. Každý z nich tedy mohl poznat trochu jiné tendence a musel se podř́dit pozměněným požadavkům. Raffael a jeho fresky podle Zlatého osla pro ně však byly stejně kanonické jako pro předcházející generace.

\section{Problems mostly iconographic}

Když zemřel Don Fabrizio, hlavní hrdina románu Gepard od Giuseppa Tomasi di Lampedusa, vrhly se jeho nábožensky založené dcery na úpravy paláce. Při zařizování kaple, která dosud v jejich domě chyběla, nechaly oškrábat barokní fresku, protože byla „sconvenientemente mitologica“. Místo ní pořídily oltář a zasadily do něj renesanční obraz v cremonském stylu. ${ }^{108}$ Po letech ale přišel na kontrolu arcidiecézní generální vikár̆, který dílo sice pochválil, ale před údajnou madonou s dopisem se na rozdíl od sester nepokř̀ižoval. Když se dostal z doslechu, zeptal se jejich kaplana, jak jen mohl sloužit mše před obrazem dívky, která čeká na milence. „Non venga a dirmi che anche Lei credeva che fosse una immagine sacra."109

Kaplan samozřejmě tušil, že nejde o posvátný obraz, ale netroufal si to říct svým paním. Zcela profánní malba tak díky kontextu, do kterého byla zasazená, sloužila jako katolický oltář a sestry Salinovy v ní bez jediné pochybnosti viděly zázračné vyobrazení Matky Boží. Humorná historka o naivní víře stárnoucích svobodných šlechtičen ukazuje extrémní případ chybné ikonografické interpretace kvůli špatnému určení žánru. Podle sira Ernsta Gombricha je správné žánrové zařazení základní východisko a nutný předpoklad každé analýzy. Ve studii Aims and Limits of Iconology zdưraznil závislost korektního čtení vizuálního materiálu na zavedených a všeobecně přijímaných kategoriích. „Without the existence of such genres in the traditions of Western art the task of the iconologist would

\footnotetext{
${ }^{106}$ Dacos, Viaggio a Roma (pozn. 90), s. 145.

${ }^{107}$ Dacos, Viaggio a Roma (pozn. 90), s. 145.

108 "Una immagine miracolosa, Monsignore, miracolosissima!" spiegò Caterina la povera inferma, sporgendosi dal suo strumento di tortura ambulante. "Quanti miracoli ha fatto!" Carolina incalzava: "Rappresenta la Madonna della Lettera. La Vergine è sul punto di consegnare la Santa Missiva ed invoca dal Figlio Divino la protezione sul popolo messinese; quella protezione che è stata gloriosamente concessa, come si è visto dai molti miracoli avvenuti in occasione del terremoto di due anni fa." "Bella pittura, signorina; qualunque cosa rappresenti è un bei quadro e bisogna tenerlo da conto." Giuseppe Tomasi di Lampedusa, Il Gattopardo, Milano 1997, s. 233-234.

${ }^{109}$ Ibidem, s. 235.
} 
indeed be desperate. If any image of the Renaissance could illustrate any text whatsoever, if a beatiful woman holding a child coud not be presumed to represent the Virgin and the Christchild, but might illustrate any novel or story in which child is born, or indeed any textbook about child-rearing, picture could never be interpreted. "110

Rudolfínská malba zahrnuje celou škálu žánrů od sakrálních témat přes alegorie, portréty a scény z každodenního života až po krajinu a zátiší. Základní určení nebývá složité a je celkem jasné, že Amor a Psýché, dominantní motiv převzatý ze Zlatého osla, patří mezi mytologie, přestože Apuleiův román jako celek mytologický není. Tím se však pouze otevírá celá řada dalších otázek. Velká část rudolfínských děl podle antických bájí má silně smyslný až erotický náboj. Musíme si proto položit otázku, jestli mytologické př́běhy tvořily pouze záminku pro dobovou alternativu pornografie, či skrývají ještě další, sofistikovanější, filosofické či morální významy nebo odkazy na jiná literární či vizuální díla. Tento problém se samozřejmě netýká pouze rudolfínského umění, ale dá se vztáhnout na velké množství sekulárních maleb 16. století, zejména těch italské provenience.

Rudolf II. je natolik výraznou osobností, že výklad děl, která objednal, získal do svých sbírek, či je pouze namalovali malíri z jeho okruhu, často svádí k psychologické interpretaci. Argumenty se přitom nabízejí pro čistě erotický výklad i pro variantu se skrytými významy a alegoriemi. Robert J. W. Evans spojil Sprangerovy odvážné kompozice s Rudolfovým milostným životem a pokusy a dojednání sňatku. „Celý tento príběh se odvijí od Rudolfovy mentální nezpưsobilosti, nikoli však od fyzické. Rudolf byl znám svými milostnými poměry. (...) Rudolfova záliba $v$ neprirozených stycích a erotice je patrná z jeho uměleckých zakázek, např́iklad ze Sprangerových smyslných pláten s nymfami obcujícími se starci." "111 Rudolfova slabost pro okultní vědy, ale také pro složité rodové a imperiální alegorie zase vedla Thomase DaCostu Kaufmanna k předpokladu, že alespoň některé erotické výjevy vyjadřovaly hlubší význam. ${ }^{112}$ Zejména zdůraznil možnost alegorického čtení u některých specifických dvojic - především ve spojení postav Merkura a Minervy, ale pravděpodobně také v prŕpadě Merkura a Psýché. ${ }^{113}$ Četnost různých motivů z př́běhu Amora a Psýché v umění Rudolfova okruhu také logicky vedla některé autory k přímému propojení tématu se slavným panovníkem a mecenášem. ${ }^{114}$ Tato lákavá interpretace ale naráží na fakt, že v řadě př́ípadů nejde o výjimečný styl ani výjimečnou ikonografii. Charakter maleb i jejich motivy mnohdy zapadají do žánrů zavedených v 16. století, jak si uvědomoval i Kaufmann. „We have already seen how the thesis that Rudolf's personal peculiarities determined the character of art done for him is problematic: what both the allegorical and idiosyncratic interpretations overlook are the sources, and indeed the generic relationships, of many Rudolfine mythologies. "115 Pro přesnější terminologii žánrů a teorii erotických obrazů, jejich význam i polemiku o nich je italské prostředí stejně zásadní jako v př́padě literárních a vizuálních vzorů.

\footnotetext{
${ }^{110}$ Gombrich, Symbolic Images (pozn. 19), s. 5.

${ }^{111}$ Evans, Rudolf II. (pozn. 22), s. 81.

112 Kaufmann, The School (pozn. 5), s. 59.

113 Ibidem.

114 Viz poznámky 7-11.

${ }^{115}$ Kaufmann, The School (pozn. 5), s. 61.
} 


\section{Bez stigmat a hřebů. Erotické obrazy}

"Ho detto a Sebastian, pittor miracoloso, che il desiderio vostro è che vi faccia un quadro de la invenzione che gli piace, purchè non ci sien su ipocrisie nè stigmati nè chiodi,"116 napsal v srpnu roku 1527 Pietro Aretino Federicu Gonzagovi. Již tři roky předtím žádal Federico svého agenta Baldassara Castiglioneho, aby mu opatřil jakýkoli obraz od Sebastiana del Piombo, jen když nebude o svatých, „ma qualche picture vaghe et belle da vedere“. ${ }^{117}$ Pěkný obraz na pohled tedy podle něj měl mít sekulární téma. Federico Gonzaga, stavebník palazza Te, dobře reprezentuje specifický druh náročných objednavatelů a sběratelů umění v 16. století, který určoval podobu mytologického žánru. ${ }^{118}$ Jeho vkus tíhl k sekulárním výjevům z antických bájí, ale z dopisu Baldassarovi Castiglionemu se zdá, že ho přesný motiv příliš nezajímal. Mnohem důležitější pro něj bylo vlastnit obraz od konkrétního mistra. Alexandr Nagel v knize The Controversy of Renaissance Art tím v podstatě vyloučil možnost existence dalších významových vrstev v těchto malbách. ${ }^{119}$

Velmi podobný přístup ke své sbírce měl o několik desetiletí později také Rudolf II., který ostatně navazoval na habsburskou rodinnou tradici a s mantovským gonzagovským dvorem byl v úzkém kontaktu. ${ }^{120}$ Podobný požadavek jako mantovský vévoda vyjádřil, když sháněl dílo Federica Barocciho. Od silně nábožensky založeného malíře žádal dílo "non di devozione ma di altro gusto". ${ }^{121}$ Barocci pro něj namaloval Aenea prchajícího z Troje, svou jedinou kompozici z římské mytologie.

Barocci pochopitelně nezvolil erotické téma, ale velkou část mytologických obrazů, která vznikala pro Rudolfa, tak vnímat můžeme. ${ }^{122}$ Povýšení Psýché na nebesa a scény, které jsou s ním spojené, nepředstavují nejprovokativnější motivy a naopak svádějí víc $\mathrm{k}$ alegorickému či neoplatónskému výkladu, přestože také v nich jsou hlavní aktéři zobrazeni nazí. Do kategorie námětů, jimž dominuje smyslné napětí mezi ústřední dvojicí, ovšem rozhodně patř́ jiný klíčový výjev mytologického příběhu z Apuleiova Zlatého osla. Představuje Psýché, jak s lampou v jedné ruce a nožem v druhé v úžasu sleduje svého neznámého milence, kterého se ještě před okamžikem chystala zabít. $V$ této situaci ji zachytil Bartholomeus Spranger v kresbě z roku kolem $1602^{123}$ a Josef Heintz v drobné virtuózní malbě na mědi. ${ }^{124} \mathrm{~V}$ Heintzově podání si Psýché tiskne jednu ruku na prso

\footnotetext{
${ }^{116}$ Nagel-Wood, Anachronic Renaissance (pozn. 77), s. 222 pozn. 7.

${ }_{117}$ Nagel-Wood, Anachronic Renaissance (pozn. 77), s. 222.

118 Bull, The Mirror (pozn. 12), s. 83. „The taste for mythological imagery was even more specific. Individual patrons had an enourmous influence. Every Catholic church needed several altarpieces; only the most ostentatiously acquisitive people needed a lot of mythological art."

119 "It would still have subject matter of some kind, though within this specifically Aretinian - Mantuan milieu there was no question that the veil would be very thin indeed." Nagel - Wood, Anachronic Renaissance (pozn. 77), s. 229.

${ }^{120}$ Venturini, Il Carteggio (pozn. 57).

${ }^{121}$ Kaufmann, The School (pozn. 5), s. 18.

122 Jako v podstatě čistě erotické vysvětluje témata ze Zlatého osla například Mungo Campbell, Mercury and Psyche (pozn. 9), s. 35.

${ }^{123}$ Sally Metzler, Bartholomeus Spranger, Splendor and Eroticism in Imperial Prague, the complete works, New Haven 2014, kat. č. 151. Leiden University Libraries (1070).

${ }^{124}$ Patrně jde o dílo, které je uvedeno pod ćíslem $30 \mathrm{v}$ seznamu obrazů, které putovaly z Prahy do Bruselu jako součást dědictví arcivévody Albrechta. Dnes Kunstsammlungen und Museen Augsburg, inv. č. 12336.
} 
a zálibně se dívá na Amora, který se slastným výrazem na tváři klidně spí. V obou případech je erotický náboj stupňován tím, že nahý Amor pouze částečně skrývá rukou své intimní partie. Jacopo Zucchi v ikonickém obraze s tímto námětem provokativně a vtipně umístil před Amora vázu s květinami. V roli pozorovatele, voyeura, ${ }^{125}$ se v tomto př́padě nachází nejen divák, ale také samotná Psýché. V grafice Jana Harmensz. Mullera podle Sprangerovy předlohy si Amor výjimečně vyměnil roli s Psýché, kterou si v údivu prohlíží. ${ }^{126}$ [obr. 5]

$\mathrm{V}$ umění rudolfinské doby se také objevuje bezprostředně následující moment, kdy Amor poté, co ho Psýché spálila olejem z lampy, opouští za dramatických okolností svou milenku. V jedné ze svých vrcholných maleb Josef Heintz zobrazil Amora, jak s lukem v ruce odchází od ležící Psýché a uraženě gestikuluje. ${ }^{127}$ [obr. 3] Kompozice vychází z grafiky z cyklu Lásky bohů od Gian Giacoma Caraglia. ${ }^{128}$ Nahá, zády otočená Psýché je zároveň citací postavy ze svatební scény ve Farnesině.

K nejoriginálnějším rudolfínským variacím na téma Amor opouští Psýché patří Sprangerův obraz na mědi z let 1599-1600. [obr. 4] Vypjatou scénu zobrazil Spranger netradičně zepředu. Pohled vede zvenku na okno, ze kterého vylétá okřridlený Amor, a Psýché se chytá jeho pravé nohy. Nahá dívka se pokouší přehoupnout přes parapet. Poloha jejího těla a pruh látky, který padá přes okraj, dodávají kompozici dynamický ráz a prohlubují iluzivní vyznění obrazu. Zdi kolem okna zdobí reliéfy, které tematicky doplňují hlavní motiv malby a vytvářejí pro něj nejen formální, ale i literární rámec. Přestože se toto dílo dá zařadit mezi eroticky laděná díla, obsahuje také řadu dalších odkazů.

Naopak do typického schématu lehce pornografických obrazů dvojic milenců patří Sprangerova kresba Amora a Psýché, pravděpodobně studie ke ztracené malbě. ${ }^{129}$ Vedle řady jejích kresebných kopií se zachoval také olej na plátně od Dirka de Quade van Ravesteyn. ${ }^{130}$ Amora a Psýché v objetí namaloval také Matthäus Gundelach. [obr. 6] Na měděné desce z roku 1613 zobrazil scénu, v níž Amor zachránil Psýché poté, co navzdory jasným instrukcím otevřela nádobu od Proserpiny a upadla do hlubokého spánku. Obraz vznikl až rok po smrti Rudolfa II., tematicky i stylově však vychází ještě z tvorby Josefa Heintze. ${ }^{131}$ Gundelach evidentně kladl větší důraz na smyslné propletení těl milenců a dokonale jemné malířské zpracování než na narativní rámec, přestože v tomto př́ípadě jde o jednu konkrétní epizodu př́iběhu.

Všechny zmíněné obrazy je tedy možné v různé míře klasifikovat jako erotické. Jakou funkci však takové výjevy plnily v 16. století? Komu byly určeny? Měl jejich mytologický námět opravdu jen zastř́it skutečný, pornografický obsah, jak v př́padě zakázek Federica Gonzagy předpokládá Alexandr Nagel? Odpověd’ na tyto obecné otázky pravděpodobně nikdy nebude definitivní, protože dokonce i v prrípadě konkrétních děl máme často k dis-

${ }^{125}$ Carlo Ginzburg, Titian, Ovid, and Sixteenth-Century Codes for Erotic Illustration, in: Clues, Myths, and the Historical Method, Baltimore 1992, s. 78.

${ }^{126}$ Meltzer, Spranger (pozn. 124), kat. č. 199.

${ }^{127}$ Germanisches Nationalmuseum Nürnberg, Inv.Nr.Gm 118, viz Gloria Ehret, Faszination Meisterwerk. Dürer Rembrandt Riemenschneider, Nürnberg 2006.

${ }^{128} \mathrm{~V}$ předchozí literatuře bývá uvedena jako vzor pouze freska ve Farnesině, ale je zřejmé, že Heintz znal i Caragliovu grafiku.

${ }^{129}$ Meltzer, Spranger (pozn. 124), kat. č. 119

${ }^{130}$ Dirk de Quade van Ravesteyn, kolem 1600, olej na plátně, Palais des Beaux Arts de Lille, inv.č. P. 2026

${ }^{131}$ Kaufmann, The School (pozn. 5), kat. č. 6.6, s. 181. 
pozici značně protichůdné informace. Pokud však chceme alespoň částečně porozumět roli, jakou hrál tento žánr v kultuře 16. století, je nezbytné se jimi zabývat.

Zásadní článek, který problematizoval ikonografii děl s erotickým podtextem v 16. století, napsal již v roce 1978 Carlo Ginzburg. ${ }^{132}$ Reagoval tím především na přístup Erwina Panofskyho v jeho posmrtně publikované knize Problems in Titian, Mostly Iconographic. ${ }^{133} \mathrm{~S}$ pomocí několika dopisů, které se týkaly Tizianových maleb, prokázal, že alespoň část jeho produkce vnímali jeho současníci jako erotickou. Ludovico Dolce velmi explicitně popsal Alessandru Contarinimu, jaký efekt vzbuzovala Tizianova Venuše a Adonis. „Ne è maraviglia, che se una statua di marmo pote in modo con gli stimuli della sua bellezza penetrar nelle midolle d' un giovane, ch'ei vi lasciò la macchia: hor, che dee far questa [Venuše z Tizianova obrazu], che è di carne; ch'è la belta istessa; che par, che spiri?" 134 Kromě toho Dolce zdůraznil zvláštní smyslnost postavy otočené zády, což by se dalo vztáhnout např́íklad také na Heintzovu Psýché. Podle Ginzburga tedy Tizianovy pozdní mytologie sloužily podobně jako pornografie a neobsahovaly další významové vrstvy. Zdánlivě neformální dopis Ludovica Dolceho, jehož obsah Ginzburg dále neinterpretoval, ovšem zčásti evokuje antické ekfráze, především Pliniův popis sochy bohyně Venuše v Naturalis historia. Nejedná se tedy o bezprostřední reakci, jak upozornil Lubomír Konečný, ${ }^{135}$ ale o záměrný odkaz, topos, který svým erotickým obsahem a klasickou formou dobře odpovídá také dvojznačnému charakteru malby 16. století.

Problémy, se kterými se Ginzburg potýkal u Tizianova díla, se do značné míry prolínají s debatou o významech v umění Rudolfova dvora. Pro klasifikaci erotických vyobrazení stanovil Ginzburg dvě základní kategorie podle toho, komu byla určená. Veřejný okruh zahrnoval sochy, fresky a velká plátna, tedy díla dostupná všem bez rozdílu sociálního postavení či vzdělání. Záměrně erotická díla se v něm v podstatě nevyskytují. Soukromý okruh tvořili elitní sběratelé, pro které vznikaly obrazy a sochy menších formátů. Exkluzivní zakázky často spojoval vybraný vizuální styl, v němž se snoubila malířská či sochařská bravura s lechtivým námětem. Jasně definované rozhraní mezi těmito dvěma okruhy zkomplikovalo rozšíření metod tisku, ale rudolfínské umění na konci 16. a začátku 17. století stále představovalo ukázkový př́klad soukromého okruhu.

Podobně skeptičtí jako Carlo Ginzburg byli ke skrytým významovým vrstvám autoři dvou recentních zásadních knih, které se obecně zabývají mytologickým žánrem v raném novověku. Malcom Bull v práci The Mirror of the Gods prezentoval diametrálně odlišný pohled na renesanční ikonografii než studie v duchu Abyho Warburga, Erwina Panofskyho či Ernsta H. Gombricha. Nezvykle bohatý vizuální materiál z území Itálie i dalších částí Evropy, který zahrnuje nejznámější díla i běžnou umělecko-řemeslnou produkci, interpretoval primárně jako nástroj k vyjádření moci nebo alternativu moderní pornografie. Leonard Barkan byl otevřenější ikonologické tradici a více zohlednil například křestanské komentáře klasické literatury. Podobně jako Bull nebo Nagel však zdůraznil, že pro renesanční mytologie je charakteristické osvobození od kosmologicky, alegoricky

${ }^{132}$ Carlo Ginzburg, Tiziano, Ovidio e i codici della figurazione erotica del Cinquecento, Paragone 29, 1978, s. 3-24. Dále citováno dle: Ginzburg, Titian (pozn. 126).

${ }^{133}$ Erwin Panofsky, Problems in Titian. Mostly Iconographic, New York 1969.

${ }^{134}$ Ginzburg, Titian (pozn. 126), s. 81, 82 citace dle: Marcia B. Hall, Tracy E. Cooper, The Sensuous in the Counter-Reformation Church, Cambridge 2013, s. 132.

${ }^{135}$ Lubomír Konečný, Tiziano, Lodovico Dolce e i topoi dell immaginazione erotica, Umění XXXX, 1991, s. $1-5$. 
a filosoficky vymezených výkladů středověku ve prospěch elegance a smyslného půvabu. ${ }^{136} \mathrm{~K}$ nově objevené tělesnosti směřoval už název jeho knihy Gods Made Flesh.

K mnohokrát přehodnocené podstatě renesanční mytologické ikonografie se v poslední době vyjádřila například také Luba Freedmanová, která v knize Classical Myths in Italian Renaissance Painting relativizovala především vysoce erudovaný, ale záměrně trochu přízemní př́stup Malcoma Bulla. ${ }^{137}$

Rozporuplné polemiky nejsou pouze záležitostí moderních dějin umění. Bohatá dobová diskuze na téma erotických obrazů a významů, které mohou skrývat, neposkytovala jednoznačnější odpovědi. Pro katolické autority v období reformace představoval potenciální silný efekt vizuálních podnětů zásadní otázku. Jezuita Johannes Molanus v traktátu De picturis et imaginibus sacris z roku 1570 varoval před všemi obrazy, které by mohly vyvolat touhu. Stejně jako Augustin pro to použil známou pasáž z Terentiovy hry Eunuchus. Mladý hrdina Chaerea pronikne v převleku za kleštěnce do domu milované dívky. Když v její koupelně spatří malbu s námětem Jupitera a Danaé, podlehne pokušení mocného boha napodobit. Tutéž pasáž citoval také dominikán Ambrogio Catarino Politi, ovšem jako analogii moci svatých obrazů vyvolat silné emoce. ${ }^{138}$

Protichůdně se různé autority stavěly také k ospravedlnění literárního či vizuálního vyprávění antických mýtů jejich alegorickým výkladem. Ludovico Dolce publikoval v roce 1554 přeloženou a přebásněnou verzi Ovidiových Metamorfóz pod názvem Le Transformationi. V elegantně zdánlivě ponížené, ale sebevědomé dedikaci císaři Karlu V. omlouval zvolené téma. „Poi qual cosa meno si conuiene a Cesare; sopra le cui spalle è piacuto alla immensa prouidenza di Dio di collcare il sostegno della religione Christiana; di quello, che è lo indizzarli fauole é amori?" 139 Své nemoudré rozhodnutí ale rychle vysvětlil. Pod povrchem vyprávění se skrývá „morale e diuina Filosofia“. Ve vydání z roku 1568 navíc připojil zbožné vysvětlující „alegorie“. ${ }^{4} 40$

V podobném duchu se vyjádřil kanovník Georgio Comanini. ${ }^{141} \mathrm{~V}$ dialogu o malbě nazvaném Il Figino se zabýval nejdiskutovanějšími teoretickými otázkami své doby - podstatou imitace, rolí umělcovy představivosti, vztahy mezi literaturou, výtvarným uměním a hudbou, nadřazeností některého $\mathrm{z}$ umění, ale také tím, jestli je důležitějším úkolem umění vzdělávat, nebo těšit. Comanini kladl velký důraz na morální a filosofický obsah. Mytologické příběhy podle něj nemá smysl malovat, pokud nevyjadřují další významy a neobsahují vyšší pravdu. Navíc ovšem nesmějí být lascivní. ${ }^{142}$

Překvapivě opatrnější postoj zaujal Jacopo Zucchi, autor mnoha mytologických fresek a obrazů, včetně slavné Psýché s lampou. V programu pro výzdobu paláce Orazia

${ }^{136}$ Leonard Barkan, The Gods Made Flesh: Metamorphosis and the Pursuit of Paganism, New Haven-London, 1986, 172-73, s. 173.

${ }^{137}$ Luba Freedman, Classical Myths in Italian Renaissance Painting, Cambridge 2015

${ }^{138}$ Ginzburg, Titian (pozn. 126), s. 77.

${ }^{139}$ Lodovico Dolce, Le Trasformationi, Venegia 1558, s. ii.

${ }^{140}$ Seznec, The Survival (pozn. 29), s. 270.

${ }^{141}$ Ibidem.

142 „Diciamo adunque, che di quel le fauole, che sono vane, \& inette, \& che non meritano il nome di fauole, huomo sauio non dee farne rappresentatione con la pittura, come di quelle, che a nulla giouano, \& nulla insegnano. Ma l'altre, le quali contengono veri sensi, \& sono acconcie ad esprimere la verità contenuta, può ben egli fare à sua voglia dipingere: pur che non contengano atti libidinosi \& forme lasciue." Gregorio Comanini, Il Figino. Overo del fine della pittura, Mantova 1591, s. 162. 
Rucellaie, který vyšel tiskem po Zucchiho smrti v roce 1602, napsal, že nikdy nepochválí toho, kdo by chtěl pod rouškou milostných příběhů a obscénních věcí ukrýt pravdu o síle a moudrosti Boží. ${ }^{143}$ Sám se však ve výkladu vlastního díla pohyboval na hraně takových alegorií. ${ }^{144}$ Nebezpečí, které představovaly křestanské komentáře, si uvědomovali také autoři tridentského seznamu zakázaných knih. Index Librorum prohibitorum neobsahoval Ovidiovy Metamorfózy, ale jejich moralizující verze. „In Ovidii metamorphoseos libros commentaria sive enarrationes allegoricae vel tropologicae. "145 Je zřejmé, že církevní cenzoři nechtěli, aby se zbožnou záminkou vycházely erotické příběhy. Eticko-morální interpretace však přesto zůstaly běžnou součástí ikonografických traktátů a manuálů. Přítel a první životopisec Bartholomea Sprangera Karel van Mander například zařadil do vlivné knihy Schilderboek také silně křest’anskou interpretaci Ovidiových Metamorfóz.

Písemné doklady o tom, jakým způsobem vnímal tento druh obrazů konkrétně Rudolf II. a lidé z jeho bezprostředního okruhu, nemáme. ${ }^{146}$ Primární pramen tak představuje především vizuální materiál. Výše citované italské texty Georgia Comaniniho se však úzce vztahují k Arcimboldovu dílu a pro rudolfínskou ikonografii je rozhodně velmi relevantní i text Jacopa Zucchiho, jehož kariéra malíre pláten a fresek s mytologickou tématikou vrcholila v době, kdy v Ř́mě pobývali také Rudolfovi hlavní figuralisté.

O přináležitosti rudolfínských maleb k italskému žánru mytologických obrazů svědčí také shodná dobová terminologie. Ve Vídeňském inventáři Rudolfových sbírek z roku 1619 i v inventáři kunstkomory z roku 1621 jsou obrazy s tématy z antických bájí několikrát popsány jako poetické a Sprangerova plátna jako „poetisch Mittelstuck“. ${ }^{47}$ Jejich označení vychází z pojmu poesie, který pro malby podle Ovidia a jiných starověkých autorů používali Ludovico Dolce a Tizian. V souvislosti s mytologickými náměty se objevuje také v Životech nejvýznačnějších malírư sochařu a architektů. Vasari jím mimo jiné uzavřel popis Raffaelovy fresky podle Apuleia ve Farnesině: „pittura e poesia veramente bellisima“. 148 Termínu poesie se v současné umělecko-historické literatuře věnovala řada autorů, $v$ souvislosti s rudolfínským uměním zejména Thomas DaCosta Kaufmann. ${ }^{149}$

143 „Se ben sò, che senza dubbio mi sará imputato (come é il vero) ad ignoranza il pensare che sotto queste scorze non ci sia suco. Dico che nol niego. Ma non loderò mai, chi con il velame degli adulterii, $i$ latroncinii, stupri, e mille cose oscene, e brutte, e con la veste della bugia, vorrá ornare, ò coprire l'istessa veritá della potenza e sapienza divina“. Giacomo [Jacopo] Zucchi, Discorso sopra li dei de gentili, e loro imprese, Roma 1602, s. 8.

144 Seznec, The Survival (pozn. 29), s. 300.

145 Ibidem, s. 275.

${ }^{146}$ Kaufmann, The School (pozn. 5), s. 60 „Yet, other than the meanings that may be extracted from the pictures themselves, there is no specific evidence, written or visual, that Prague erotica were meant to be read in this manner."

${ }^{147}$ Kaufmann, The School (pozn. 5), s. 61.

148 Freedman, Classical Myths (pozn. 138), s. 196.

${ }^{149}$ Kaufmann, The School (pozn. 5), s. 61. K problematice a původu slova poesie v Tizianově díle mimo jiné: Lubomír Konečný, The Poetry of Titian's "Poesie”: the Renaissance, in: György E. Szönyi - Csaba Maczelka (edd.): Centers and Peripheries in European Renaissance Culture. Essays by East-Central European Mellon Fellows, Szeged 2012, s. 223-230; Freedman, Classical Myths (pozn. 138), zvl. s. 201 a následující; Fernando Checa, Tizian und die Mythologie, in: Sylvia Ferino-Pagden (ed.), Der späte Tizian und die Sinnlichkeit der Malerei, Wien 2007, s. 216-223. 


\section{Amor. Più giovane di tutti i Dei}

Quicumque ille fuit, puerum qui pinxit Amorem, nonne putas miras hunc habuisse manus? is primum vidit sine sensu vivere amantis, et levibus curis magna perire bona. idem non frustra ventosas addidit alas, fecit et humano corde volare deum: scilicet alterna quoniam iactamur in unda, nostraque non ullis permanet aura locis. et merito hamatis manus est armata sagittis, et pharetra ex umero Cnosia utroque iacet: ante ferit quoniam, tuti quam cernimus hostem, nec quisquam ex illo vulnere sanus abit. ${ }^{150}$

V jedné ze svých elegií chválí Propertius zázračnou ruku prvního malíře, který namaloval Lásku jako chlapce s lukem a šípy, protože v jeho podobě vystihl dětinský charakter a neposednost ošemetného citu i rány, které umí uštědřit. Amor zobrazený jako hravé dítě $s$ krátkými kř́dly dominoval velké části renesančního i pozdějšího umění a patří mezi notoricky známé figury. Ernstu Gombrichovi posloužila socha okř́idleného chlapce z londýnského Piccadilly Circus od Alberta Gilberta k demonstraci prchavosti významů v umění, protože ji všichni považují za mytického bůžka Kupida, přestože měla původně představovat křestanskou lásku. ${ }^{151}$ Jak ale trefně poznamenal Charles Dempsey, ukazuje naopak nepochybnou stálost některých ikonografických typů a Gilbertovu naivitu, když předpokládal, že by mohl přesvědčit obyvatele Londýna, že ve skutečnosti jde o jednu z teologických ctností. ${ }^{152} \mathrm{~V} 16$. století však Amor postupně získával ještě jinou, dospělejší, smyslnější a mnohdy také krutější identitu.

V roce 1601 způsobila rozruch Caravaggiova odvážná kompozice Amor Vincit Omnia, která představila Venušina syna jako rozesmátého mladíka se šípy v ruce pohodlně rozkročeného nad rozházenými symboly lidských pozemských snah, umění a věd, marných tváŕí v tváŕ lásce. Caravaggiův rival Giovanni Baglione zareagoval na posměšnou malbu postupně dvěma obrazy, na nichž jeden okřídlený mladík, personifikace nebeské lásky, bije druhého, personifikaci pozemské lásky. Přestože to jistě nebylo účelem, nechybí ani této zbožně motivované scéně erotický náboj. Toho využil jiný Caravaggiův současník a následník Bartolomeo Manfredi, když vtipně parafrázoval Baglioneho malbu. $\mathrm{V}$ jeho podání trestá Amora Mars, jehož ruku se pokouší zadržet Venuše. Žádná z těchto kompozic by nebyla srovnatelně efektní, pokud by boha lásky představovalo obtloustlé dětátko. Apuleiův Zlatý osel sehrál roli v této proměně Amora v dospívajícího muže, který se objevoval také na obrazech z Rudolfova okruhu.

Amor figuruje $\mathrm{v}$ celé řadě bájí, ale pouze $\mathrm{v}$ př́padě př́běhu Psýché jako jeden $\mathrm{z}$ hlavních hrdinů. V Apuleiově vyprávění se ožení a zplodí s Psýché dítě, což od začátku vedlo k jeho zobrazením ve vyšším věku. Jako starší chlapec je zobrazen již na florentských

\footnotetext{
${ }^{150}$ Propertius, Elegie II,12.

${ }^{151}$ Gombrich, Symbolic Images (pozn. 19), s. 1-5.

${ }^{152}$ Charles Dempsey, Inventing the Renaissance Putto, Chapel Hill 2001, s. 4.
} 
svatebních truhlicích a až na výjimky se z toho stalo pravidlo i v následujících stoletích. Značná část $\mathrm{z}$ těchto obrazů však ani zdaleka nemá silnější erotický podtext a je dalece vzdálená Caravaggiovu provokativnímu Amorovi. Vysloveně v úloze milence ho patrně poprvé namalovali až florentští manýristé Jacopo Pontormo a Agnolo Bronzino. ${ }^{153}$ V obou př́padech jde o alegorická vyobrazení Venuše v objetí s Kupidem. Ve stejné době jako Pontormova známá malba podle Michelangelova kartonu vznikl také Parmigianinův Amor vyřezávající luk, obraz, který v roce 1605 získal do Prahy Rudolf II. Originální námět rezonoval mezi jeho dvorními malíri a Josef Heintz, který obraz restauroval, podle něj vytvořil přesnou kopii. Variaci namaloval také Bartholomeus Spranger. ${ }^{154}$ Enigmatická malba, která předtím patřila do madridských sbírek Filipa II., představila typ Amora později charakteristický také pro Sprangera, Heintze nebo Gundelacha. Dvojici soupeřících putti navíc uplatnil Josef Heintz také v obraze Amor opouští Psýché.

Pro tuto novou Amorovu podobu je klíčový jeho podrobný evokativní popis ze Zlatého osla. Apuleius vylíčil krásu mladého boha lásky, kterou spatřila Psýché, když se k němu přiblížila s lampou v ruce (Met, V, 22). ${ }^{155}$ Tato část textu vykazuje kvality, pro něž Giovanni Andrea de Bussi, editor prvního vydání, nazval Apuleiův styl malířským. Zaujala také autory novověkých manuálů a traktátů o ikonografii a často je jedinou částí příběhu o Psýché, kterou převyprávěli. Gian Paolo Lomazzo ji citoval v Trattato dell'arte della pittura, scoltura et architektura z roku $1584^{156}$ a Vicenzo Cartari dokonce uvedl, že Amora nejpodrobněji „namaloval“ Apuleius: „più minutamente lo dipinse Apuleio nella nouella di psiche." 157

Psýché s lucernou patří k nejběžněji zobrazovaným samostatně stojícím výjevům ze Zlatého osla a popis Amora z této pasáže ovlivnil jeho podobu také v ostatních malbách rudolfínského manýrismu. Elegantní stylizovaná kabinetní díla určená pouze úzkému okruhu diváků představovala ideální médium. Zejména drahé precizní olejomalby na mědi poskytovaly možnost vystihnout hru světla a stínu, drobné detaily i jemnost kůže. Nizozemští rytci navíc dokázali zprostředkovat vybraný styl rudolfinské malby i v grafice. Společně s charakterem výtvarné techniky se změnil i charakter postavy. Coxcieho Amor, který dominoval velkým italským narativním cykli̊m ve fresce i bruselským tapisériím, ${ }^{158}$ se svým vzhledem zdaleka neblíží ideálnímu milenci z Apuleiova popisu. Popularita př́běhu mezi rudolfínskými mistry sice jednoznačně souvisela s Raffaelovou lodžií a s grafikami podle Coxcieho, ale smyslná postava boha lásky vycházela víc $\mathrm{z}$ Parmigianinova Amora, ale také z často citované části Apuleiova textu.

${ }^{153}$ Kingsley-Smith, Cupid (pozn. 15), s. 138.

${ }^{154}$ Lubomír Konečný, Cupid Carving His Bow. From Parmigianino to Rubens, Source. Notes in the History of Art XXXIV, no. 1, 2014, s. 24-31.

155 „Sed cum primum luminis oblatione tori secreta claruerunt, videt omnium ferarum mitissimam dulcissimamque bestiam, ipsum illum Cupidinem formonsum deum formonse cubantem, cuius aspectu lucernae quoque lumen hilaratum increbruit et acuminis sacrilegi novaculam paenitebat. (...) Videt capitis aurei genialem caesariem ambrosia temulentam, cervices lacteas genasque purpureas pererrantes crinium globos decoriter impeditos, alios antependulos, alios retropendulos, quorum splendore nimio fulgurante iam et ipsum lumen lucernae vacillabat; per umeros volatilis dei pinnae roscidae micanti flore candicant et quamvis alis quiescentibus extimae plumulae tenellae ac delicatae tremule resultantes inquieta lasciviunt; ceterum corpus glabellum atque luculentum et quale peperisse Venerem non paeniteret. Ante lectuli pedes iacebat arcus et pharetra et sagittae, magni dei propitia tela."

156 Giovanni Paolo Lomazzo, Trattato dell'arte della pittvra, scoltvra, et architettvra, Milano 1584, s. 369.

157 Vicenzo Cartari, Le imagini degli dei degli antichi, Venetia 1625, s. 371.

158 Thomas P. Campbell, Tapestry in the Renaissance. Art and Magnificence, New York 2002, s. 271. 
V Le imagini degli dei degli antichi Cartari napsal, že Amor je „bellissimo, perche é piu giouane di tutti i Dei“.159 Oproti své nejběžnější podobě ale musel trochu zestárnout, aby zastal roli děsivě krásného milence Psýché. V druhé polovině 16. století dokonce jeho italská a později také rudolfinská nová vizuální identita převládla natolik, že pravděpodobně ovlivnila anglickou literaturu, především vzkvétající alžbětinské drama. Na možnou souvislost těchto dvou fenoménů upozornila Jane Kingsley-Smithová v knize Cupid in Early Modern Literature and Culture. „But despite the difficulty of tracing precise lines of influence, the ways in which Cupid was eroticized in Italian Renaissance painting (the combination of a childish face, with a muscled, adolescent body); the kinds of desire he produces (heteroerotic, homoerotic and pederastic); even the attitude towards sex that he suggests (amoral, exploitative) are intriguingly analogous to Cupidas he was sometimes conceived of on the early modern stage. "160 Kromě maleb florentských manýristů Pontorma a Bronzina zmínila badatelka výslovně ve vztahu k proměně postavy Amora na divadelní scéně také Sprangerovy obrazy a Goltziovy grafiky. ${ }^{161}$

\section{Psýché. Arte et ingenio stat sine morte decus}

„Who cares whether Pandora had a large pithos or a small pyxis? No one, not even an archeologist. Yet, this is far from being the case. This is no mere blunder, best corrected and quickly buried out of sight. It is one of the vital errors that breed the corruption of a total mythological misconception. "162 Jane Ellen Harrisonová, významná britská klasická filoložka, v roce 1900 jako první upozornila na přkekvapivě závažnou záměnu velké schránky (pithos) za malou skř́ńnku (pyxis) v mýtu o Pandoře. Podle Harrisonové ustálené, ale chybné spojení Pandory se skř́inkou (box) vedlo k nepochopení důležitých aspektů antického mýtu a jeho souvislostí se svátky mrtvých. Př́činu tohoto omylu odhalili Dora a Erwin Panofští o více než padesát let později. S největší pravděpodobností za ním stál Erasmus Rotterdamský, který v knize komentovaných pořekadel Adagiorum chiliades tres propojil postavu Pandory s Apuleiovou Psýché a nádobou s „trochou Proserpininy krásy“, kterou měla donést Venuši, ale málem zemřela, když ji navzdory instrukcím sama otevřela. ${ }^{163}$ Obě př́liš zvědavé dívky tak v tradici novověkého západního umění nesou stejný atribut, malou skřriňku nebo vázičku, a bez dalších informací může dojít k jejich záměně. Problematická se ukázala dvojice Merkura a Psýché, kterou na nebesa vynášejí amoretti. V katalogu Rijksmusea z roku 1955 dokonce neslo sousoší Adriana de Vries absurdní název „Psýché s Pandořinou skřiňkou“. ${ }^{164}$ Některá vyobrazení Psýché proto představují

${ }^{159}$ Cartari, Le imagini (pozn. 157), s. 371.

${ }^{160}$ Kingsley-Smith, Cupid (pozn. 15) s. 142.

161 Ibidem.

162 Jane E. Harrison, Pandora's Box, The Journal of Hellenic Studies Vol. XX, 1900, s. 99-114, cit. s. 100; viz také: Vered Lev Kenaan, „Who cares whether Pandora had a large pithos or small axis?" Jane Harrison and the Emergence of a Dynamic Conception of the Unconscious, in: Vanda Zajko - Ellen O'Gorman (eds.), Classical Myth and Psychoanalysis. Ancient and Modern Stories of the Self, Oxford 2013, s. 97-116.

${ }^{163}$ Dora Panofsky - Erwin Panofsky, Pandora's Box. The Changing Aspects of a Mythical Symbol, New York 1962, s. 18.

164 Ibidem, s. 20. 
pro manžele Panofské podobně ukázkový ikonografický oříšek jako Judita a Salomé. ${ }^{165}$ Ve dvojici s Merkurem by navíc Psýché žádnou nádobu nést neměla, protože podle Apuleiova př́běhu ji už předala Venuši. Merkur ji vynáší na nebesa, kde ji čekají olympští bohové, svatební hostina a její budoucí manžel Amor.

V rudolfínském umění sporná nádobka evidentně sloužila jako atribut Psýché. S drobnou skleněnou pyxidou ji namaloval Bartholomeus Spranger v obraze, který se po mnoha letech objevil nedávno v soukromé německé sbírce. ${ }^{166}$ Jedná se pravděpodobně o první malbu, kterou se Spranger prezentoval Rudolfu II. v roce $1576 .{ }^{167}$ Je zajímavé, že první dílo Andriana de Vries pro císaře také představovalo Psýché s vázičkou v ruce. Vriesova bronzová socha vychází z Raffaelovy fresky ve Farnesině, na které Psýché doručuje Proserpininu krásu Venuši. Vries ji pravděpodobně znal z grafiky. ${ }^{168}$ Bezprostředně poté vytvořil ještě dvojici Merkura a Psýché se stejnou nádobou v ruce. ${ }^{169} \mathrm{~V}$ Raffaelově malbě i grafice podle ní má přitom Psýché korektně prázdné ruce.

Zdá se tedy, že došlo k propojení dvou po sobě následujících scén, z nichž je z narativního hlediska jednoznačně důležitější povýšení Psýché na nebesa. Přestože se jedná o vrchol příběhu, zásadní také v morálních a křestanských interpretacích, ve kterých Psýché reprezentuje duši, nebyl tento výjev mimo rudolfínský okruh samostatně zdaleka tak častý jako například scéna s lampou. Thea Vignau-Wilbergová mu proto ve své studii o umělecké teorii ve výtvarných dílech pro Rudolfa II. přikládala podobnou váhu jako Hermathéně, alegorické dvojici Merkura a Minervy ${ }^{170}$ nebo „významově závažným“ grafikám podle předloh Hanse von Aachena a Bartholomea Sprangera týkajícím se postavení umělců a malírství. ${ }^{171}$

Za základ pro interpretaci Merkura a Psýché použila badatelka grafické listy podle kreseb Pietera Bruegela, které vyryl Cornelius Cort a vydal Joris Hoefnagel. [obr.] Merkura unášejícího Psýché doplňuje Ikarův pád. Obě kompozice tvoří převážně krajina, v níž se téměř ztrácejí mytologické postavy. Hoefnagel ke grafikám připojil motta a vysvětlující dvojverší, která Thea Vignau-Wilbergová vztáhla také na Vriesovy sochy a Sprangerovy malby a kresby. Krajina s Merkurem a Psýché nese nápis „Arte et ingenio stat sine morte decus“, tedy „dovedností a přirozeným talentem je toto skvělé dílo nesmrtelné, a verše:

Pulcher Atlantiades Psychen ad Sydera tollens,

Ingenio scandi Sydera posse docet

Ingenio liquidum possum conscedere Coelum,

Si mundi curas fata levare velint

„Krásný Atlasův vnuk (Merkur), který unáši Psýché do nebe, ukazuje, že díky přirozenému talentu může vystoupit ke hvězdám. Mohu vstoupit na jasné nebe díky svému priroze-

\footnotetext{
${ }^{165}$ Erwin Panofsky, Význam ve výtvarném umění, Praha 1981, s. 33-52

${ }^{166}$ Catherine Hickley, Christie's to auction long-lost painting by Mannerist artist Spranger, The Art Newspaper, 4. 10. 2017, https://www.theartnewspaper.com/news/christies-to-auction-long-lost -painting-by-mannerist-artist-spranger, vyhledáno dne 9. 7. 2018.

${ }_{167}$ Metzler, Spranger (pozn. 124), kat. č. 19, s. 89-90.

${ }^{168}$ Frits Scholten (ed.), Adriaen de Vries 1556-1626, Amsterdam-Stocholm-Los Angeles 1999, s. 106.

169 Ibidem, s. 109.

170 Thea Vignau-Wilberg, Grafika a teorie (pozn. 7), s. 185.

${ }^{171}$ Ibidem, s. 180.
} 
nému nadání, pokud hodlá osud ulehčit starostem světa." ${ }^{172}$ Koncept nutnosti kombinace přirozeného nadání, ingenium, a umělecké dovednosti, ars, vychází z Horatiova díla Ars poetica a zdůraznil ho také Karel van Mander ve svém teoretickém traktátu Grondt der edel vry schilder-const. Ikarův pád demonstruje potřebu rovnováhy mezi principy, které personifikují postavy Merkura (Ars) a Psýché (Ingenium).

Thea Vignau-Wilbergová viděla v grafikách, malbách a sochách, které reflektovaly dobovou uměleckou teorii, důkaz o spojení humanistické a výtvarné kultury na Rudolfově dvoře v osobě vzdělaného malíre. Pictor doctus podle ní představoval typ, který Rudolf II. aktivně vyhledával. V kontextu těchto úvah je zajímavé zvážit, jakou roli mohlo hrát vyobrazení Merkura a Psýché ve výměně názorů, zkušeností a v rivalitě mezi císařovými umělci.

Nejprve Konrad Oberhuber a později Thomas DaCosta Kaufmann se zaměřili na souvislosti tvorby Adriana de Vries a Bartholomea Sprangera. Podle Kaufmanna vzájemné citace a parafráze v jejich dílech připomínají soutěžení mezi výtvarnými disciplínami, dobře známé zejména $\mathrm{z}$ florentské teorie umění pod pojmem paragone. ${ }^{173}$ Kaufmann sledoval podobnosti ve stylu i námětech a zdůraznil jejich spolupráci na společných projektech a sdílenou zkušenost s Giambolognovými sochami a florentskými uměleckými kruhy. Snad nikoli náhodou tak Sprangerovo první a De Vriesovo druhé dílo pro císaře shodně představují dvojici Merkura a Psýché, alegorii úspěšné kombinace dovedností nezbytných pro umělce. Zásadní součástí diskuzí o nadřazenosti sochařství nebo malby byla otázka více úhlů pohledu. Argument, který měl nahrávat trojrozměrnému médiu, využívali i malíŕi, kteří mohli zachytit mnoho různě natočených postav na jediném plátně, jak demonstroval anekdotou o Giorgionově obrazu se zrcadlem Giorgio Vasari. ${ }^{174}$ Z Vasariho historky v úvodu k Životům je zřejmé, že řada komentářu a názorů ve věci paragone měla v 16. století vizuální podobu. Záhy po dokončení De Vriesova sousoší Merkura a Psýché podle něj vznikla grafika Jana Mullera, která dvojici zobrazovala ze tří pohledů. Na Mullerově listě je patrné jak De Vriesovo mistrovství v kompozici, tak schopnost plošného média tyto kvality zachytit.

Za další vizuální příspěvek do rudolfínské debaty o paragone bychom mohli považovat také Sprangerovu malbu Amor opouští Psýché. [obr. 4] Dynamická pozice ústředního páru předčí lehkostí Giambolognovy a De Vriesovy sochy, přestože se subtilností a rovnováhou pohybují na technologické hranici možného. Výjev navíc v pozadí doplňuje namalované sousoší, obdoba De Vriesových bronzů. Fasádu Amorova paláce, iluzivní rámec obrazu, pokrývají reliéfy z kamene i kovu, čímž Spranger výborně demonstroval schopnost malby imitovat sochařská díla. Sám měl ostatně pravděpodobně s tímto médiem zkušenosti. Žádné jeho sochy se dodnes sice nezachovaly, ale podle nápisu na grafice Amor a Psýché ji Jan Muller vytvořil na základě Sprangerova terakotového reliéfu. [obr. 5]

\footnotetext{
172 Ibidem, s. 183.

173 Thomas DaCosta Kaufmann, A “modern” sculptor in Prague. Adriaen de Vries and the 'Paragone' of the Arts, in: Achim Gnann - Heinz Widauer (edd.), Festschrift für Konrad Oberhuber, Milano 2000, s. $283-293$, cit. s. 283.

${ }^{174}$ Giorgio Vasari, Le vite de piu eccellenti pittori, scultori e architetti, vol. 1, Firenze 1846, s. 90. „varie vedute (...), che ha una statua sola“
} 
Zvyšující se zájem o teorii paragone $\mathrm{v}$ průběhu 16 . století lze částečně spojit s větším využíváním soch jako prototypů pro malbu, a to jak v dílenské kresliŕské praxi, tak v hotových zakázkách, často inspirovaných antickými díly. ${ }^{175}$ Citace starověkých předloh patřily také do repertoáru rudolfínských malíruu, kteři tím, že prokázali jejich znalost, naplňovali dobové představy o učených umělcích. Pro postavu Psýché existovalo v 16. století hned několik antických předobrazů. Na konci 16. století šlo o již mnohokrát použité a různě přetvořené vzory s mnoha kulturními konotacemi. Přesto je vysoce pravděpodobné, že si umělci z Rudolfova okruhu uvědomovali a oceňovali jejich starověký původ. Tvrzení Soni Cavicchioli, že "per questi pittori l'immagine di psiche non ha certo radici archeologiche, ed e invece un prodotto del Rinascimento, riconosciuto universalmente come età dell oro mitica e normativa, "176 proto není zcela pravdivé, přestože z větší části samozřejmě skutečně měla rudolfínská ikonografie svůj základ v italském 16. století.

Na některých grafikách podle Coxcieho se objevuje mírně přikrčená Psýché, jejiž pozice vychází z římské kopie helénistické sochy, kterou vlastnil nejprve Agostino Chigi a později byla vystavena ve vile d'Este v Tivoli. ${ }^{177}$ [obr. 10] V Coxcieho vlivném cyklu však Psýché nemá na rozdíl od antické předlohy křídla. Velmi podobnou postavu včetně křídel namaloval Josef Heintz v rozměrném obraze s námětem Faëthontova pádu. [obr. 11] Vyobrazil ji v předním plánu mezi héliovnami, dcerami boha slunce a sestrami Faëthona. Podle Ovidia truchlily pro svého bratra tak dlouho, až je bohové proměnili $\mathrm{v}$ topoly. Okř́dlená nymfa v Heintzově malbě se však vymyká běžné ikonografii. Není bez zajímavosti, že podle Boccaccia byla také Psýché dcerou Apollóna, ale pro propojení těchto dvou mýtů neexistuje žádný precedens, a nezdá se proto př́liš pravděpodobné.

S postavou Psýché byl spojován také slavný rímský reliéf zvaný Polykleitovo lože, který vlastnil Lorenzo Ghiberti a později ho do sbírek získal Rudolf II. [obr. 7] Vzhledem k velkému množství různých kopií však není zcela jisté, jestli šlo skutečně o originál, který je dnes nezvěstný ${ }^{178}$ Zobrazuje ženu sedící na posteli, která se otáčí, aby přikryla svého spícího milence. V obrazech ji parafrázovali Raffael, Giulio Romano i Tizian. Psýché v podobné pozici zařadil do cyklu grafik Lásky bohů Gian Giacomo Caraglio a variaci jeho kompozice namaloval Josef Heintz.

\section{Dobrý konec vše napraví}

Př́běh krásné Psýché začíná a končí svatbou. Na jeho začátku však připomíná spíš pohřební průvod, když se Psýché loučí se svými príbuznými, aby se oddala manželovi podobnému víc drakovi než člověku, jak předpovědělo orákulum. Skutečná svatba na konci je o poznání veselejší událost. Jupiter vyhověl Amorově prosbě a pozdvihl Psýché mezi bohy, kde na ni čekala velká oslava. Nejambicióznější kompozici s námětem z Apuleiova Zlatého osla nakreslil mezi lety 1583 a 1585 Bartholomeus Spranger. Svatební hostinu Amora a Psýché tvoři kolem sedmdesáti figur zasazených v oblacích. Přes neuvěritelné

\footnotetext{
${ }^{175}$ Francis Ames-Lewis, The Intellectual Life of the Early Renaissance Artist, New Haven 2000, s. 153.

176 Cavicchioli, Le metamorfosi (pozn. 8), s. 173.

177 Phylis Pray Bober - Ruth Rubinstein, Renaissance Artists \& Antique Sculpture. A Handbook of Sources, London-Turnhout, s. 140.

${ }^{178}$ Ibidem, s. 139.
} 
množství postav se Sprangerovi podařilo vytvořit harmonickou scénu, která učarovala Karlu van Manderovi a díky němu inspirovala celou generaci holandských malíruo . V Schilderboeck, knize která propagovala vlámskou malbu podobně jako Vasariho Životy florentskou, věnoval Mander pozornost vytváření prostoru v obrazech italských a nizozemských malírù. Kromě krajinomalby, tradiční domény záalpských mistrů, zdůraznil také cit svých krajanů pro doorsien, přirozeně komponovaný průhled do dálky v mnohafigurálních výjevech. V této souvislosti se dokonce odvážil kritizovat Michelangelův Poslední soud, protože jeho plošná kompozice dostatečně nevedla oko diváka do nitra obrazu. ${ }^{179}$ Důležité Manderovi připadalo také rozdělení postav do skupin, uzlů (knoopen), které měly vlastní narativní nebo alegorický význam. ${ }^{180}$ Za dokonalý příklad považoval právě Sprangerovu kresbu, podle které Hendrick Goltzius vytvořil v roce 1587 slavnou mědirytinu. [obr. 12] Goltziova grafická verze umožnila rozšíření Spragerovy bravurní manýristické vizuální skladby po Evropě. V několika malbách ji přetvořil například holandský malíř Joachim Wtewael. ${ }^{181}$

Goltziovu grafiku doprovází text, který shrnuje příběh Amora a Psýché a s lehkostí vlastní rudolfínskému umění ho také interpretuje. Už připomínka na jeho začátku, volně přeložitelná jako „pokud učený Apuleius nelže“, 182 naznačuje, v jakém duchu se nese výklad komplikovaného výjevu. Závěrečná část opět elegantně zpochybňuje vážnost následujícího moralizujícího vysvětlení. „Si licet ex finctis quicquam decepere very. / Mel legere instar apis, virusque relinqure Arachnae, / Et gentilitios non exhorrescere fumos: Psyche haec, illa Anima est divino aequata decori."183 "Je-li možné z fiktivních př́běhư získat pravdu, sbirat med jako včely a jed nechat pavoukưm a nebát se pohanských znameni," pak je Psýché podle veršů pod Goltziovou grafikou Duše, povýšená na nebesa, její sestry dábelské pokušitelky a Amor božský zachránce, s nímž Psýché zplodí Voluptas. Jedna ze sester je popsána jako Carnis - tedy stejně jako ve Fulgentiově známém alegorickém výkladu. Spranger nebo Goltzius ho mohli znát například z nesmírně vlivného komentáře k Apuleiově Zlatému oslu od Fillipa Beroalda, který ho hojně citoval, ale zároveň jako přehnaně př́ísný odmítl. ${ }^{184}$

Tón popisu pod Goltziovou grafikou podle Sprangerovy kresby vypovídá mnohé o podstatě rudolfinských mytologií. Klade důraz na narativní složku, která je podána v povedené zkratce, odkazuje k autoritě antického spisovatele Apuleia, ale zároveň mírně zpochybňuje jeho důvěryhodnost a s lehkou nadsázkou předkládá také závěrečné morální poučení. Dokonce ani dobové vysvětlení tak nedává jasnou odpověd' na otázky, které si kladou dnešní erudovaní ikonologové. Díla rudolfínských umělců bezpochyby mohla obsahovat to, čemu Carlo Ginzburg říkal druhá významová vrstva a co se mu nedařilo najít, nebo to snad najít nechtěl, v pozdních Tizianových poesiích. V prrípadě Amora a Psýché však tato vrstva měla velmi daleko k závažnému pojetí v duchu Fulgentiovy

\footnotetext{
${ }^{179}$ Martha Hollander, An Entrance for the Eyes: Space and Meaning in Seventeenth-Century Dutch Art, Berkeley 2002, s. 10.

180 Ibidem, s. 11.

${ }^{181}$ Anne W. Lowenthal, Desire and Devotion in Wtewael's Art, in: James Clifton - Liesbeth M. Helmus Arthur K. Wheelock, Jr. (ed.), Pleasure and Piety: the Art of Joachim Wtewael, Princeton 2015, s. 1-16, cit. s. 9 , kat.č. 18.

182 Doprovodný text pod grafikou, viz Metzler, Spranger (pozn. 124), kat. č. 178, s. 288-290.

${ }^{183}$ Ibidem.

${ }^{184}$ Zimmerman, Food for Thought (pozn. 25), s. 223.
} 
nebo Boccacciovy náročné exegeze. Jejich limitované, elitní a vzdělané publikum nejen chápalo, ale pravděpodobně očekávalo citace moderních i antických děl, znalo Apuleia a různé interpretace jeho Zlatého osla, ale u smyslného př́iběhu o lásce, zvědavosti a dobrých koncích se chtělo především chytře bavit. Důležité je, že kromě císaře, spřízněných panovníků a jejich dvořanů tvořili toto obecenstvo také sami umělci, kteří v Praze získali za vlády Rudolfa II. výrazně lepší postavení než kdykoli předtím. Dvojice Merkura a Psýché pravděpodobně představovala v rudolfínském kontextu ideální kombinaci přirozeného nadání a naučené zručnosti, která vede ke slávě. Také jiné výjevy z Apuleiova Zlatého osla v podání Rudolfových dvorních malíruo odkazují k hravému soupeření mezi jednotlivými mistry i mezi technikami.

\section{Asinus portans mysteria}

Cesta k pochopení specifické atmosféry, ve které vznikala díla předních rudolfínských figuralistů, vede mimo jiné do Ríma. Ve vile Agostina Chigiho poznali nejen příběh Amora a Psýché, ale také tlak mezinárodní konkurence a touhu vyrovnat se Raffaelovu mistrovství, jak ukazuje Belloriho anekdota o Baroccim. Postavení umělců, které se v Itálii během 15. a 16. radikálně změnilo, se také více či méně evidentně promítlo do námětů a charakteru jejich tvorby. Spranger, Aachen a Heintz se pohybovali v prostředí, kde vznikl cyklus Federica Zuccariho o strádání a úspěších jeho slavného bratra Taddea. Podle formátu kreseb je zřejmé, že jde o předlohu pro nástěnné malby. Pravděpodobně měly zdobit stěny Federicova římského domu. Ve své závěti z roku 1603 Federico vyjádřil přání, aby palazzo Zuccarri sloužilo k ubytování a vzdělávání mladých chudých umělců, kteří přicestovali do Ř́ma, ${ }^{185}$ a výjevy z Taddeova raného života by se pro takový účel výborně hodily. Jejich témata, jako kopírování podle antických soch i moderních malířů stejně jako uvědomění si vlastního postavení, představovala běžnou součást života římského malíře na konci 16. století a pronikla také do děl těch, kteří Ř́mem prošli.

Apuleiův Zlatý osel patřil do této kultury v mnoha rovinách. Sehrál zásadní roli v etablování fikce jako samostatného a plnohodnotného žánru a stojí tak na počátku dominantní role románu v novodobé literatuře. Podle Carvera $\mathrm{k}$ tomu došlo postupně, nejprve ospravedlněním smyšlených př́běhů skrze alegorickou interpretaci a teprve na sklonku 16. století uznáním jejich úplné autonomnosti. „The triumph of fiction has taken place in two stages: the first task was to justify the value of fiction in the face of powerful detractors-philosophers and the Church-and allegory was a valuable ally in this campaign. The second stage occurs relatively late in the Renaissance: the final escape from allegory and the proclamation of the autonomous value of fiction. In both these campaigns, Apuleius' novel figures prominently. " 186 Paralelním procesem prošla v 16. století také vizuální mytologická narace. Leonard Barkan zdůraznil, že inovace renesančních obrazů spočívá v osvobození pohanských př́běhů od přidaných významů, „from cosmological, allegorical and philosophical constraints" ${ }^{187}$ Neznamená to, že by taková interpretace zcela zmizela

185 Brooks, Taddeo and Federico (pozn. 99), s. 117.

${ }^{186}$ Carver, The Protean Ass (pozn. 3), s. 144.

${ }^{187}$ Barkan, The Gods Made Flesh (pozn. 137), s. 173. 
ze zřetele, ale vyprávění děje a naturalistický charakter postav získávaly postupně na váze. Zejména postava Amora v rudolfínském umění je toho dobrým př́íladem. Senzualita mnohdy převládala nad ostatními složkami rudolfínského umění. Úplnou absenci dalších významů však také můžeme vyloučit. Dospělého Amora často doprovází soupeřící putti, kteří podle Cartariho ${ }^{188}$ představují opětovanou lásku, a Kupid zhášející pochodeň reprezentující naopak amor Letheo, zapomnění milované osoby. [obr.] Psýché měla alegorický smysl především ve dvojici s Merkurem a text pod Goltziovou grafikou zmiňuje moralizující výklad příběhu Amora a Psýché. Zásadní ale v případě Zlatého osla zůstávalo vyprávění.

Velké nástěnné cykly a tapisérie podle Coxcieho grafik nezačínají rovnou mytologickou pohádkou, ale první scéna patří do narativního rámce Zlatého osla. Lucius v podobě osla, v doprovodném textu k rytinám ve vydání Antonia Salamancy ztotožněný s Apuleiem, poslouchá stařenu, která vypráví mladé dívce o lásce a strádání Amora a Psýché. I v prrípadě vizuálních verzí se tedy jedná o prríběh v příběhu a záměrné zdůraznění, že jde o malovanou fikci. Autor předlohy je mnohem více přítomen než u jiných sekulárních námětů. Takto ho znali jistě i rudolfínští umělci, ačkoli v jejich dílech se Apuleius v oslí podobě neobjevoval. V roli vypravěče figuruje např́iklad v textu pod Goltziovou Svatbou Amora a Psýché.

Osel, který chybí v obrazech Bartholomea Sprangera, Hanse von Aachena, Josefa Heintze nebo v sochách Adriana de Vries, figuruje v grafice Jana Sadelera podle emblému Andrea Alciata Non tibi sed religioni. Na zádech má připevněn idol, kterému se klaní kolem stojící lidé. ${ }^{189}$ Hloupé zvíře se mylně domnívá, že pocty patří jemu. Námět vychází především z Babriových Fabulae Aesoepae, ale souvisí také s Apuleiem. Původní bajka zmiňuje pouze posvátný obraz, ale díky komentáři Erasma Rotterdamského došlo k propojení tohoto př́běhu se závěrem Apuleiova Zlatého osla, kde je popsán průvod bohyně Isis. ${ }^{190}$ Verše k Alciatovu emblému uvedené také pod Sadelerovou grafikou proto znějí:

Isidis effigiem tardus gestabat asellus,

Pando verenda dorso habens mysteria.

Obvius ergo Deam quisquis reverenter adorat,

Piasque genius incipit flexis preces.

Ast asinus tantum praestari credit honorem

Sibi, et intumescit admodum superbiens.

Donec eum flagris comspescens dixit agaso,

Non es Deus tu asselle, sed Deum vehis. ${ }^{191}$

Erasmus zahrnul Apuleia a kult východní bohyně do výkladu rčení Asinus portans mysteria v knize Adagia. Př́ísloví se vztahuje k někomu, kdo vykonává práci, na niž nemá potřebnou kvalifikaci. Jako př́iklad uvedl Erasmus negramotného knihovníka. Tváří

188 Cartari, Le imagini (pozn. 157), s. 364.

${ }^{189}$ Lubomír Konečný, Adaptations of Alciato's emblems by Jan and Raphael Sadeler, Studia Rudolphina X, 2010, s. 129-143, cit. s. 130, 135.

${ }^{190}$ Ilja Markx-Veldman, The Idol on the Ass; Fortune and the Sleeper. Maarten Van Heemskerck's Use of Emblem and Proverb Books in Two Prints, Simiolus: Netherlands Quarterly for the History of Art, vol. VI, no. 1,1972 , s. $20-28$, cit. s. 22-23.

${ }^{191}$ Konečný, Adaptations (pozn. 189), s. 135. 
v tvář množství primární i sekundární literatury k druhému životu Apuleiova slavného románu a jeho vizuálnímu zpracování není téměř možné nestát v podobné roli. Citované texty i zmíněná umělecká díla představují pouze zlomek z toho, co by mohlo být pro rudolfínskou ikonografii relevantní. Také Apuleiův Zlatý osel nadále ponese svá tajemství a nepřestane lákat generace ikonologů k odvážným hypotézám. Ernst Gombrich na něm Z velké části postavil interpretaci Botticelliho Primavery. Díky jeho brilantnímu podání stále slouží tato $\mathrm{v}$ mnoha ohledech kontroverzní a $\mathrm{v}$ detailech překonaná studie jako jeden ze základních textů pro studium významu ve výtvarném umění novověku. Mladý Anthony Blunt věnoval svo̊j první článek v nově založeném časopise Warburgova institutu Hypnerotomachii Poliphili, ${ }^{192}$ knize, která se stala jednou z největších renesančních literárních poct Apuleiovu dílu. ${ }^{193}$ Pro Fritze Saxla představovaly Raffaelovy fresky v lodžii Amora a Psýché „the greatest effort to illustrate pagan myth in the spirit of the classical marbles as they reappeard from beneath the Roman soil." 194

Zkoumání ikonografie podle Zlatého osla se stalo modelovým příkladem, o kterém psala řada nejvýznamnějších světových badatelů. Otevírá řadu zásadních otázek o podstatě renesance a jejím vztahu k antice, ale také o vyprávění profánních příběhů v literární i vizuální podobě, vlivu knihtisku a grafiky na šíření klasické vzdělanosti a originalitě v umělecké tvorbě. V podobě dílčí studie by v ideálním případě mohl příklad cesty Amora a Psýché z Itálie na Rudolfův pražský dvưr a do jeho okolí osvětlit široké spektrum problémů a fenoménů spojených s unikátním stylem internacionální manýrismu na přelomu 16. a 17. století. Velmi zajímavé se jeví například souvislosti mezi výtvarnou kulturou v Itálii a v Praze a literární tvorbou v Anglii. S nabývajícím množství informací z různých společensko-vědních oborů je možné takové studie neustále opakovat beze strachu, že osel jednou přijde o všechna svá tajemství.

\section{SUMMARY}

\section{The Golden Ass of Apuleius and the Classical Literary Tradition in the Visual Arts of the Rudolphine Period}

Only one of many Ancient Roman novels that were written during antiquity has survived to this day. Apuleius' Metamorphoses could have easily been lost too as it was overlooked by the Carolingian renaissance and at one point existed only in a single copy. Luckily it was found and rediscovered for the Italian Renaissance by one of the so called bookhunters in the 14th century. After that it did not cease to inspire many works of art from literature to paintings. The story of Cupid and Psyche that comes from this book was used to decorate many representational rooms from the early Renaissance on, until at least the 19th century. It seems to have been especially popular at the court of Rudolf II and it represents one of the typical mythological themes with a strong erotic potential.

\footnotetext{
192 Blunt, The Hypnerotomachia (pozn. 58).

${ }^{193}$ Carver, The Protean Ass (pozn. 3), s. 173: „Indeed, the Borgia papacy witnessed the erection of the Italian Renaissance's two greatest literary monuments to Apuleius, the anonymous Hypnerotomachia Poliphili (1499) and Filippo Beroaldo's massive folio edition (with commentary) of The Golden Ass (1500)".

${ }^{194}$ Fritz Saxl, The Villa Farnesina, in: Lectures, 1957, s. 189-199, cit. s. 192-5.
} 
We can trace its roots to Italy where the novel was brought back to the literary scene. The most important visual sources, that played at least an equally important role in the dissemination of the motive through Europe as literature, also come from Italy. Especially Rome and Raphael's frescos in villa the Farnesina influenced generations of Italian as well as foreign artists. Bartholomeus Spranger, Joseph Heintz and other future court artists of Rudolf II were no exception. The antique city and antique novel inspired their works but they also added their own unique approach to the Italian tradition. This work follows the reception of the famous Golden Ass in a time, when the possibilities of printing techniques radically changed rules of the game. It also opens the question of meaning in the art of the Rudolphine Period. To what extent were the secular works meant as objects of sensual pleasure and on the other hand how important were the allegorical explanations of the story of Cupid and Psyche.

\section{VÝBĚROVÁ BIBLIOGRAFIE}

Mariantonietta Acocella, L' Asino d'oro nel Rinascimento. Dai volgarizzamenti alle raffigurazioni pittoriche, Ravenna 2001.

Francis Ames-Lewis, The Intellectual Life of the Early Renaissa nce Artist, New Haven 2000.

Leonard Barkan, The Gods Made Flesh: Metamorphosis and the Pursuit of Paganism, New Haven-London 1986.

Giovanni Pietro Bellori: Le vite de pittori, scultori ed architetti moderni, Roma 1728.

J. R. Berrigan, ‘The Prehumanism of Benzo d'Alessandria', Traditio XXV, 1969, s. 253-254.

Giuseppe Billanovich, I primi Umanisti e le tradizioni dei classici latini, Fribourg 1953.

Anthony Blunt, The Hypnerotomachia Poliphili in 17th Century France, Journal of the Warburg Institute Vol. 1, No. 2, 1937, s. 117-137.

Phylis Pray Bober - Ruth Rubinstein, Renaissance Artists \& Antique Sculpture. A Handbook of Sources, London-Turnhout 2010.

Giovanni Boccaccio, Genealogy of the pagan gods [Orig.: Genealogia deorum], přeložil Jon Solomon, Cambridge, Mass. 2011.

Julian Brooks, Taddeo and Federico Zuccaro. Artist-brothers in Renaissance Rome, Los Angeles 2007.

Malcolm Bull, The Mirror of the Gods. Classical Mythology in Renaissance Art, London 2005.

William Caferro, Contesting the Renaissance, Oxford 2011.

Mungo Campbell, Mercury and Psyche - Muller after De Vries, History Today, May 1994, s. 30-35.

Thomas P. Campbell, Tapestry in the Renaissance. Art and Magnificence, New York 2002

Vicenzo Cartari, Le imagini degli dei degli antichi, Venetia 1625.

Robert H. Carver, The Protean ass: the "Metamorphoses" of Apuleius from antiquity to the Renaissance, Oxford 2008.

Sonia Cavicchioli, Le metamorfosi di Psiche. L'iconografia della favola di Apuleio, Venezia 2002.

Miguel de Cervantes Saavedra, Don Quijote de la Mancha, překlad J. B. Pichl, Praha 1866.

Fernando Checa, Tizian und die Mythologie, in: Sylvia Ferino-Pagden (ed.), Der späte Tizian und die Sinnlichkeit der Malerei, Wien 2007, s. 216-223.

Via Claudia Cieri Via, L' arte delle metamorfosi: decorazioni mitologiche nel Cinquecento, Roma 2003.

James Clifton - Liesbeth M. Helmus - Arthur K. Wheelock Jr. (ed.), Pleasure and Piety. The Art of Joachim Wtewael, Princeton 2015.

Richard Cocke, Titian the Second Apelles: the Death of Actaeon, Renaissance Studies, Vol. 13, No. 3, 1999, s. 303-311.

Gregorio Comanini, Il Figino. Overo del fine della pittura, Mantova 1591.

Ioan P. Couliano, Eros and Magic in the Renaissance, Chicago 1987.

Ernst Robert Curtius, Evropská literatura a latinský středověk, Praha 1998.

Nicole Dacos, Fiamminghi a Roma 1508-1608, Roma 1999.

Nicole Dacos, Viaggio a Roma. I pittori europei nel '500, Milano 2012. 
J. F. D'Amico, The Progress of Renaissance Latin Prose. The Case of Apuleianism, Renaissance Quarterly XXXVII, 1984, s. 364-365.

Charles Dempsey, Inventing the Renaissance Putto, Chapel Hill 2001.

Lodovico Dolce, Le Trasformationi, Venegia 1558.

Richard Dutton - Jean E. Howard, A Companion to Shakespeare's Works: The Poems, Problem Comedies, Late Plays, b. m. 2007.

Umberto Eco, Foucaultovo kyvadlo, Praha 2015.

Gloria Ehret, Faszination Meisterwerk. Dürer Rembrandt Riemenschneider, Nürnberg 2006.

George Eliot [Mary Ann Evans], Middlemarch. A Study of Provintial Life, Edinburgh - London 1874.

Robert J. W. Evans, Rudolf II. a jeho svět, Praha 1997.

Elena Fontanella (ed.), Amore e Psiche. La favola dell'anima, Milano 2013.

Luba Freedman, Classical Myths in Italian Renaissance Painting, Cambridge 2015.

Eliška Fučíková - James M. Bradburne - Beket Bukovinská - Jaroslava Hausenblasová - Lubomír Konečný - Ivan Muchka - Michal Šroněk (eds), Rudolf II. a Praha: císařský dvůr a rezidenční město jako kulturní a duchovní centrum střední Evropy, Praha - Londýn - Milán 1997.

Julia Haig Gaisser, The fortunes of Apuleius and the "Golden Ass" : a study in transmission and reception, Princeton 2008.

Carlo Ginzburg, Titian, Ovid, and Sixteenth-Century Codes for Erotic Illustration, in: Clues, Myths, and the Historical Method, Baltimore 1992.

Ernst Hans Gombrich, Symbolic Images. Studies in the art of the Renaissance II, Oxford 1985

Stephen Greenblatt, The Swerve. How the World Became Modern, New York 2011.

Marcia B. Hall - Tracy E. Cooper, The Sensuous in the Counter-Reformation Church, Cambridge 2013.

Jane E. Harrison, Pandora's Box, The Journal of Hellenic Studies Vol. 20, 1900, s. 99-114.

Martha Hollander, An Entrance for the Eyes: Space and Meaning in Seventeenth-Century Dutch Art, Berkeley 2002.

Koenraad Jonckheere (ed.), Michiel Coxcie 1499-1592 and the giants of his age, London 2013.

Ahuvia Kahane - Andrew Laird (eds), A Companion to the Prologue of Apuleius' Metamorphoses, Oxford 2001.

Thomas DaCosta Kaufmann, L'école de Prague. La peinture a la cour de Rodolphe II, Paris 1985.

Thomas DaCosta Kaufmann, Eros et poesia. La peinture à la cour de Rodolphe II, Revue de l'art, 1985, s. 29-46.

Thomas DaCosta Kaufmann, The School of Prague. Painting at the court of Rudolf II, Chicago 1988.

Thomas DaCosta Kaufmann, A “modern” sculptor in Prague. Adriaen de Vries and the 'Paragone' of the Arts, in: Achim Gnann - Heinz Widauer (eds), Festschrift für Konrad Oberhuber, Milano 2000, s. 283-293.

Thomas DaCosta Kaufmann, Arcimboldo. Visual Jokes, Natural History, and Still-life Painting, Chicago 2009.

Vered Lev Kenaan, „Who cares whether Pandora had a large pithos or small axis?“ Jane Harrison and the Emergence of a Dynamic Conception of the Unconscious, in: Vanda Zajko - Ellen O'Gorman (eds), Classical Myth and Psychoanalysis. Ancient and Modern Stories of the Self, Oxford 2013, s. 97-116.

Jane Kingsley-Smith, Cupid in Early Modern Literature and Culture, Cambridge 2010.

Susanne H. Kolter, Bartholomaus Spranger „Amor und Psyche“ im Kontext rudolfinischer Hofkunst, Jahrbuch des Landesmuseums für Kunst und Kulturgeschichte Oldenburg 2008, s. 12-21.

Lubomír Konečný, Tiziano, Lodovico Dolce e i topoi dell immaginazione erotica, Umění XXXX, 1991, s. $1-5$.

Lubomír Konečný - Štěpán Vácha, Hans von Aachen in Kontext, Praha 2012.

Lubomír Konečný, Adaptations of Alciato’s emblems by Jan and Raphael Sadeler, Studia Rudolphina X, 2010, s. 129-143.

Lubomír Konečný, The Poetry of Titian’s “Poesie”: the Renaissance, in: György E. Szönyi - Csaba Maczelka (eds), Centers and Peripheries in European Renaissance Culture. Essays by East-Central European Mellon Fellows, Szeged 2012, s. 223-230.

Lubomír Konečný, Cupid Carving His Bow. From Parmigianino to Rubens, Source. Notes in the History of Art XXXVI, no. 1, 2014, s. 24-30.

Milan Kundera, Zneuznávané dědictví Cervantesovo, Brno 2005. 
Paolo Lomazzo, Trattato dell'arte della pittvra, scoltvra, et architettvra, Milano 1584.

Martin Mádl (ed.) Tencalla II. Barokní nástěnná malba v českých zemích, Praha 2013.

Ilja Markx-Veldman, The Idol on the Ass; Fortune and the Sleeper. Maarten Van Heemskerck's Use of Emblem and Proverb Books in Two Prints, Simiolus: Netherlands Quarterly for the History of Art, vol. 6, no. 1, 1972, s. 20-28.

Sally Metzler, Bartholomeus Spranger, Splendor and Eroticism in Imperial Prague, the complete works, New Haven 2014.

Jacqueline Marie Musacchio, Art, Marriage, \& Family in the Florentine Renaissance Palace, New Haven 2008.

Alexander Nagel, Merchant of Venice, Art Forum, January 2007, s. 109.

Alexander Nagel - Christopher S. Wood, Anachronic Renaissance, New York 2010.

William R. Newman - Anthony Grafton (eds), Secrets of Nature Astrology and Alchemy in Early Modern Europe, Cambridge, Mass. 2001.

Dora Panofsky - Erwin Panofsky, Pandora's Box. The Changing Aspects of a Mythical Symbol, New York 1962.

Erwin Panofsky, Renaissance and Renascences in Western Art, Stockholm 1965.

Erwin Panofsky, Problems in Titian. Mostly Iconographic, New York 1969.

Erwin Panofsky, Význam ve výtvarném umění, Praha 1981.

Francesco Petrarca, Le Familiari. Edizione critica per cura di Vittorio Rossi, vol. III, Firenze 1997.

Ivo Purš - Hedvika Kuchařová (eds), Knihovna arcivévody Ferdinanda II. Tyrolského (1529-1595), Praha 2016.

Evelyn Reitz, Discordia concors. Kulturelle Differenzerfahrung und ästhetische Einheitsbildung in der Prager Kunst um 1600, Berlin 2015.

Emil Karel Josef Reznicek, Bartholomäus Spranger als Bildhauer, in: Antje Kosegarten - Peter Tigler (eds), Festschrift Ulrich Middeldorf, Textband, Berlin 1968, s. 370-375.

G. N. Sandy, 'Book 11: Ballast or Anchor?', in: B. L. Hijmans - R. Th. van der Paardt (eds), Aspects of Apuleius' Golden Ass, Groningen 1978, s. 123-140.

Fritz Saxl, The Villa Farnesina, in: Lectures, b. m. 1957, s. 189-199.

Jean Seznec, The Survival of the Pagan Gods. The Mythological Tradition and Its Place in Renaissance Humanism and Art, New York 1961.

Frits Scholten (ed.), Adriaen de Vries 1556-1626, Amsterdam-Stocholm-Los Angeles 1999.

J. J. M. Tobin, Shakespeare's Favorite Novel. A Study of The Golden Asse as Prime Source, London 1984.

Giuseppe Tomasi di Lampedusa, Il Gattopardo, Milano 1997.

Giorgio Vasari, Vita di Perino del Vaga, in: Opere di Giorgio Vasari. Pittore e Architetto Aretino. Volume II, Firenze 1822.

Giorgio Vasari, Le vite de'piu eccellenti pittori, scultori e architetti, vol. 1, Firenze 1846.

Elena Venturini (ed.), Le collezioni Gonzaga. Il Carteggio tra la corte cesarea e Mantova (1559-1636), Carteggio, Cinisello Balsamo 2002.

Luisa Vertova, Cupid and Psyche in Renaissance Painting before Raphael, Journal of the Warburg and Courtauld Institutes Vol. 42, 1979, s. 104-121.

Florian Weiland-Pollerberg, Amor und Psyche in der Renaissance. Medienspezifisches Erzahlen im Bild, Petersberg 2004.

Evelyn Welch, Presentism and the Renaissance and Early Modern Historian, Past \& Present, Volume 234, Issue 1, 2017, s. 245-253.

Jürgen Zimmer, Joseph Heintz der Ältere als Maler, Weissenhorn 1971.

Maaike Zimmerman, 'Food for Thought' for Readers of Apuleius' The Golden Ass, in: Michael Paschalis - Stelios Panayotakis - Gareth L. Schmeling (eds), Readers and Writers in the Ancient Novel, Ancient Narrative Supplements 12, 2009, s. 218-240.

Giacomo [Jacopo] Zucchi, Discorso sopra li dei de' gentili, e loro imprese, Roma 1602. 


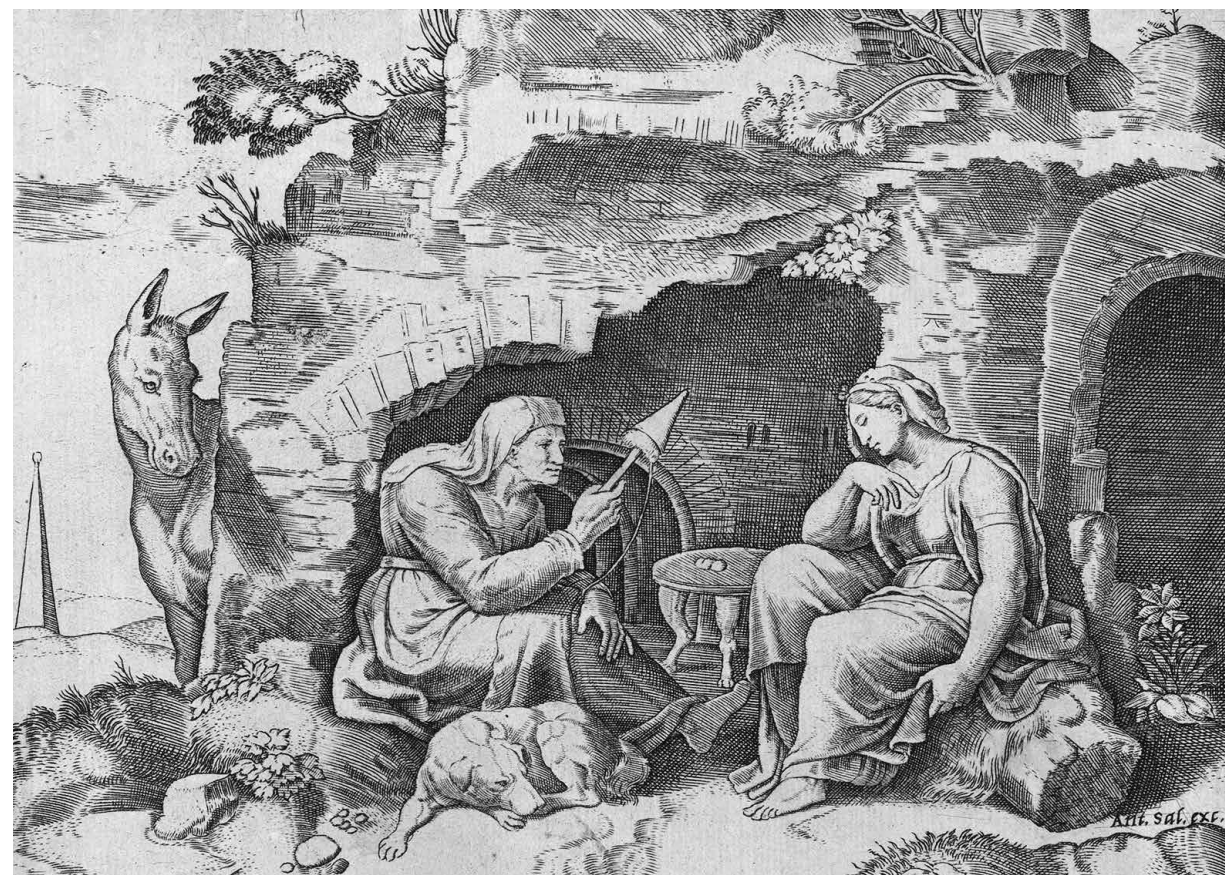

Obrázek 1. Mist B s kostkou podle Michiela Coxcieho, Stařena vypráví príiběh Amora a Psyché, list ze série grafik podle Apuleiova Zlatého osla, 1530-1560, vydal Antonio Salamanca v Římě. Reprodukce ze stránek Rijksmuseum Amsterdam, RP-P-H-H-793, http://hdl.handle.net/10934/RM0001.COLLECT .219664 (CC0 1.0 Universal)

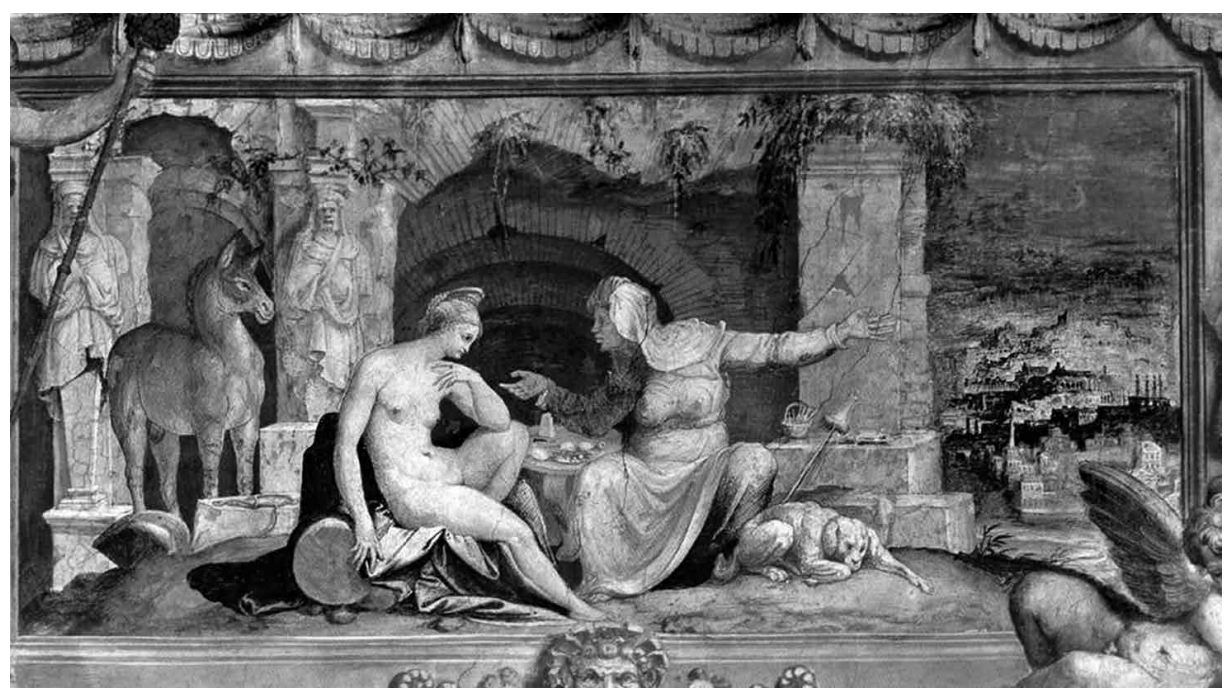

Obrázek 2. Perin del Vaga, Stařena vypráví príběh Amora a Psyché, Castel Sant'Angelo, 1545. Reprodukce z knihy Maria Grazia Bernardini (ed.), La favola di Amore e Psiche. Il mito nell'arte dall'antichitá a Canova, Roma 2012, s. 86 

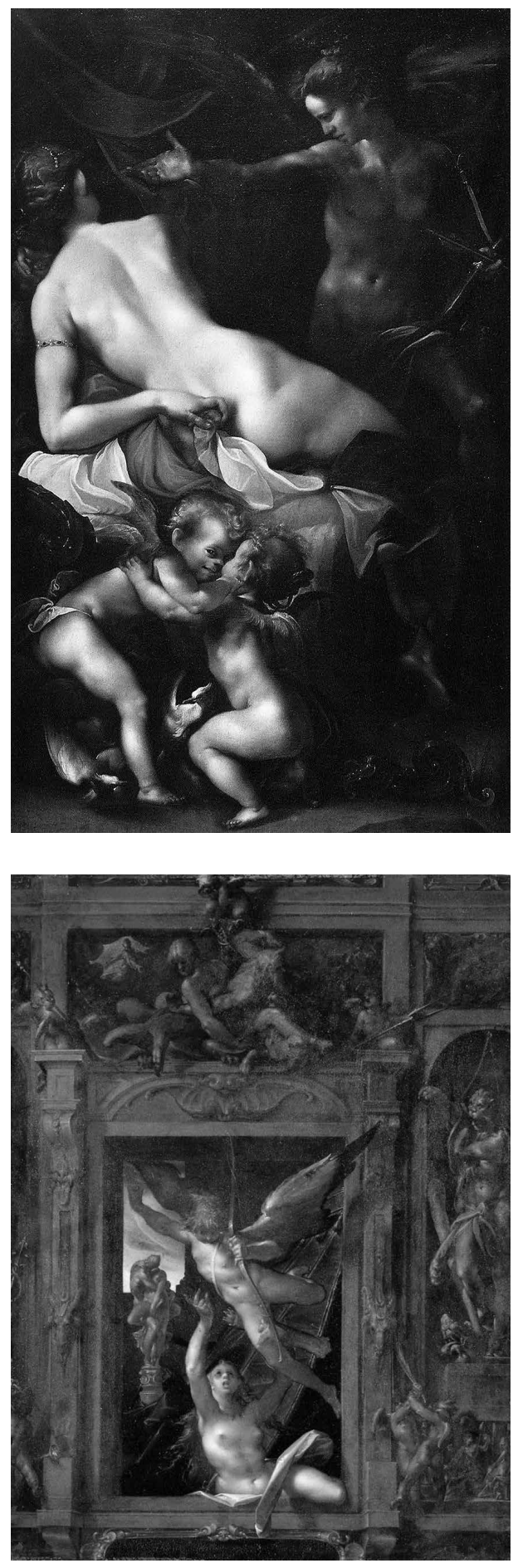

Obrázek 3. Josef Heintz, Amor opouští Psyché, po 1603 , Germanisches Nationalmuseum, Nürnberg, inv. č. Gm1118. Reprodukce z knihy Daniel Hess - Dagmar Hirschfelder (eds), Renaissance, Barock, Aufklärung. Kunst und Kultur vom 16. bis zum 18. Jahrhundert, Germanisches Nationalmuseum, Nürnberg 2010, s. 275

Obrázek 4. Bartholomeus Spranger, Amor opouští Psyché, 1599, Landesmuseum für Kunst und Kulturgeschichte Oldenburg, 15-579. Reprodukce z knihy Sally Metzler, Bartholomeus Spranger: Splendor and Eroticism in Imperial Prague, the complete works, New Haven 2014, kat. č. 73, s. 149 


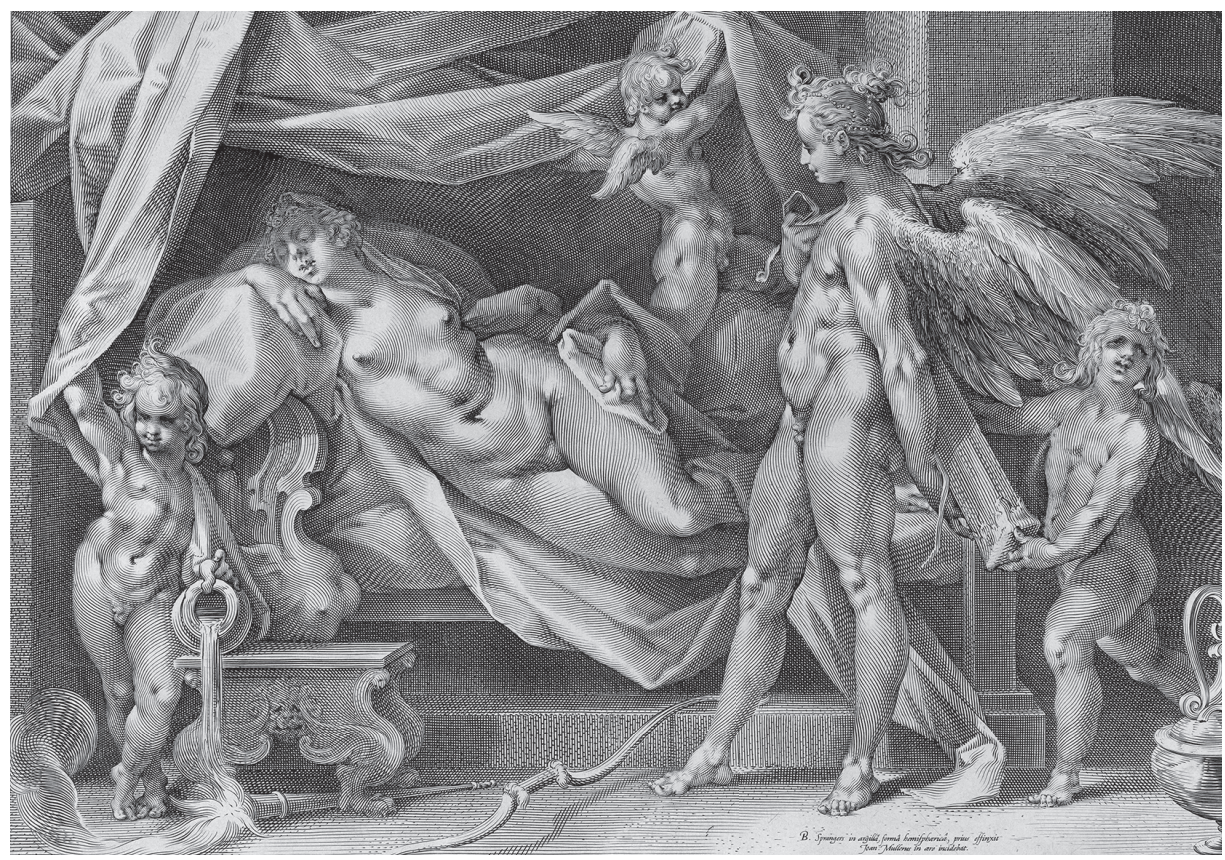

Obrázek 5. Jan Harmensz. Muller podle Bartholomea Sprangera, Amor a Psyché, 1600-1610, tisk 1610. Reprodukce ze stránek Rijksmuseum Amsterdam, RP-P-OB-32.216, http://hdl.handle.net/10934 /RM0001.COLLECT.337222 (CC0 1.0 Universal)

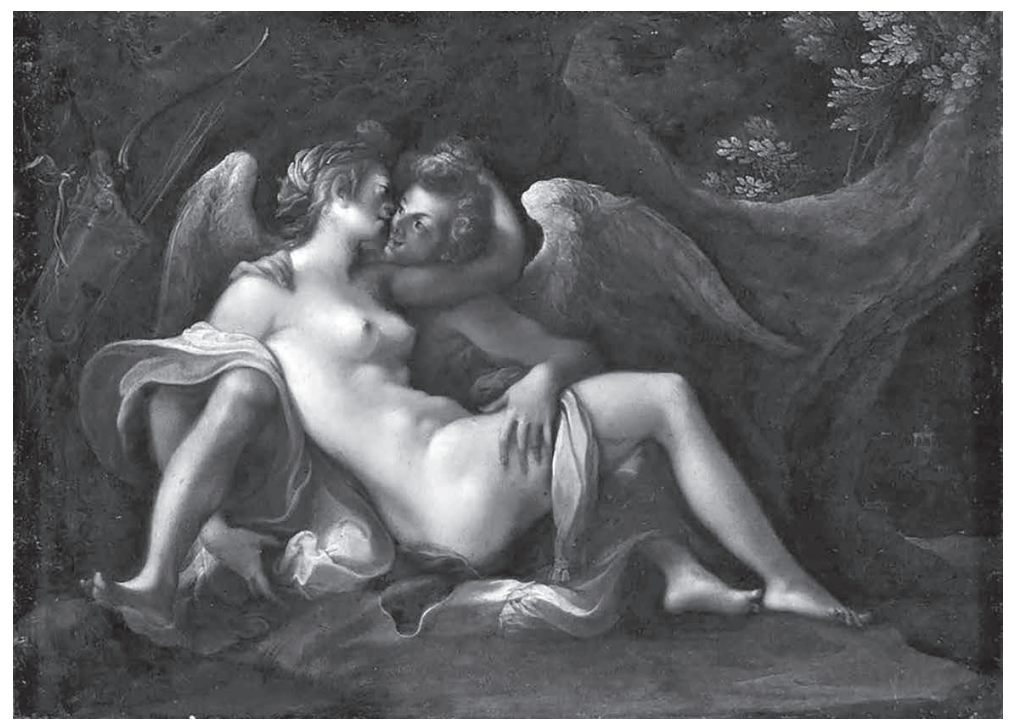

Obrázek 6. Matthäus Gundelach, Amor a Psyché, 1613, Augsburg, Deutsche Barockgalerie, inv. č. 724. Reprodukce z knihy Eliška Fučíková - James M. Bradburne - Beket Bukovinská - Jaroslava Hausenblasová - Lubomír Konečný - Ivan Muchka - Michal Šroněk (eds), Rudolf II. a Praha císařský dvưr a rezidenční město jako kulturní a duchovní centrum střední Evropy, Praha-Londýn-Milán 1997, s. 64 


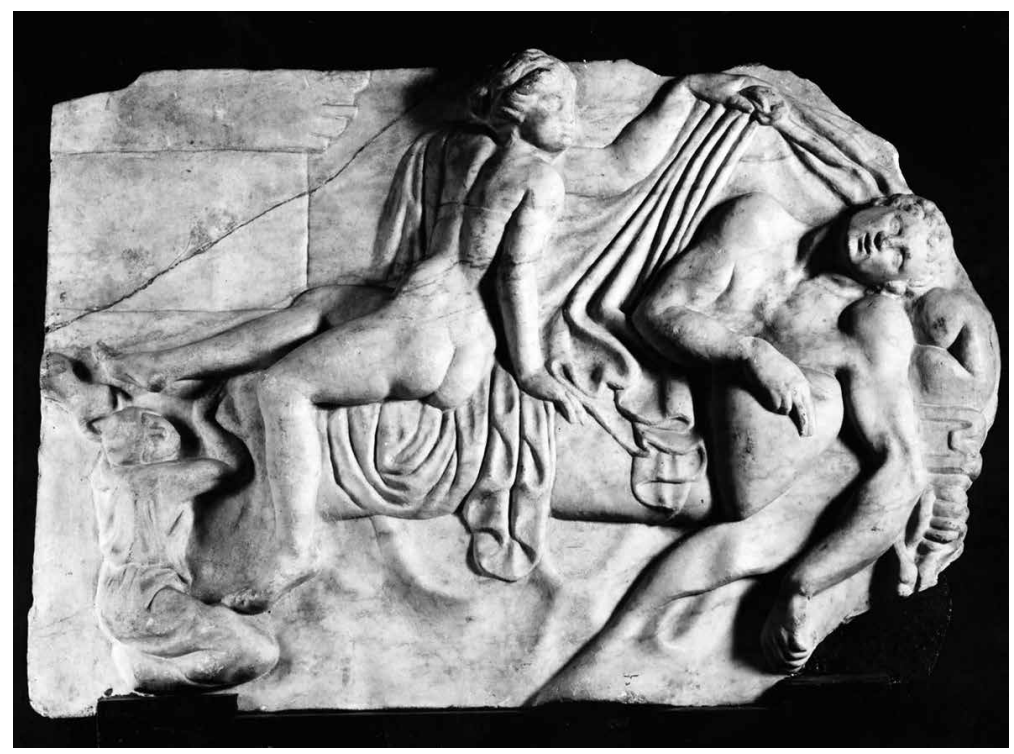

Obrázek 7. Ř́mský reliéf Polykleitovo lože, Amor a Psyché, kopie z 16. století. Reprodukce z knihy Phylis Pray Bober - Ruth Rubinstein, Renaissance Artists \& Antique Sculpture. A Handbook of Sources, London-Turnhout 2010, snímek 94

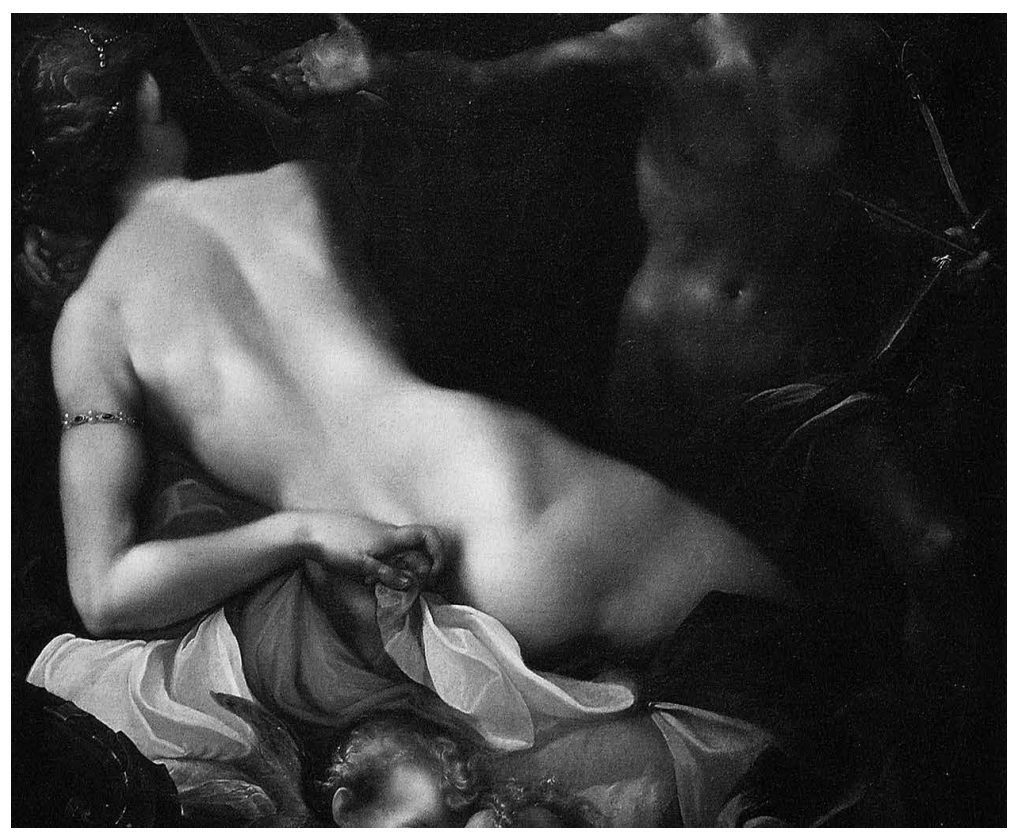

Obrázek 8. Josef Heintz, Amor opouští Psyché, detail, po 1603, Germanisches Nationalmuseum, Nürnberg. Reprodukce z knihy Daniel Hess - Dagmar Hirschfelder (eds.), Renaissance, Barock, Aufklärung. Kunst und Kultur vom 16. bis zum 18. Jahrhundert, Germanisches Nationalmuseum, Nürnberg 2010, s. 275 


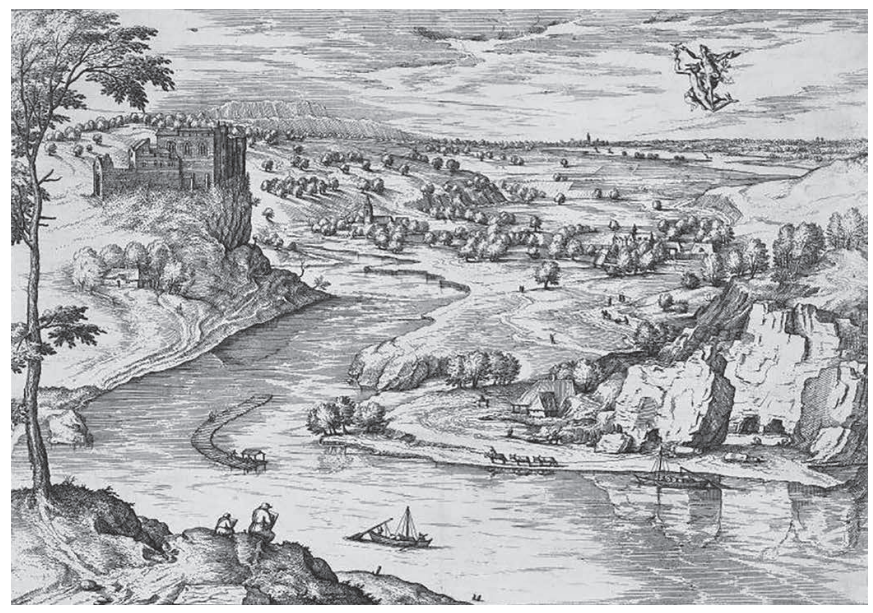

Obrázek 9. Cornelius Cort podle Pietera Bruegela, Krajina s Merkurem unášejícím Psyché, 1553, vydal Joris Hoefnagel. Reprodukce z knihy Eliška Fučíková - James M. Bradburne - Beket Bukovinská - Jaroslava Hausenblasová - Lubomír Konečný - Ivan Muchka - Michal Šroněk (eds), Rudolf II. a Praha císařský dvůr a rezidenční město jako kulturní a duchovní centrum střední Evropy, Praha-Londýn-Milán 1997, s. 182

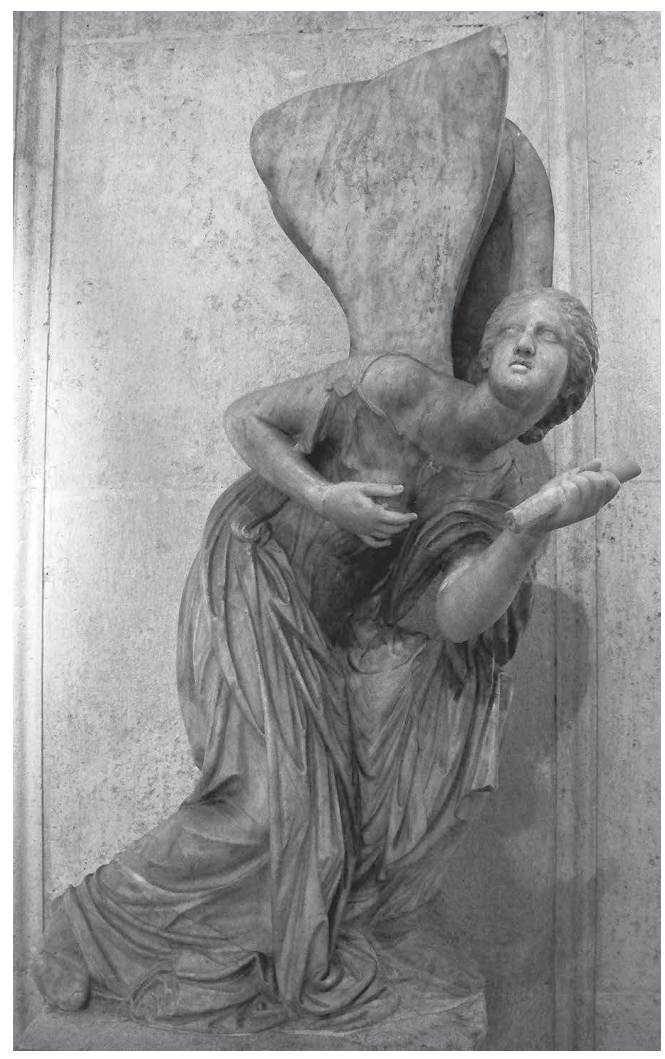

Obrázek 10. Ǩímská kopie řecké sochy, $P s y$ ché, Museo Capitolino. Reprodukce z knihy Phylis Pray Bober - Ruth Rubinstein, Renaissance Artists \& Antique Sculpture. A Handbook of Sources, London-Turnhout 2010, snímek 95 


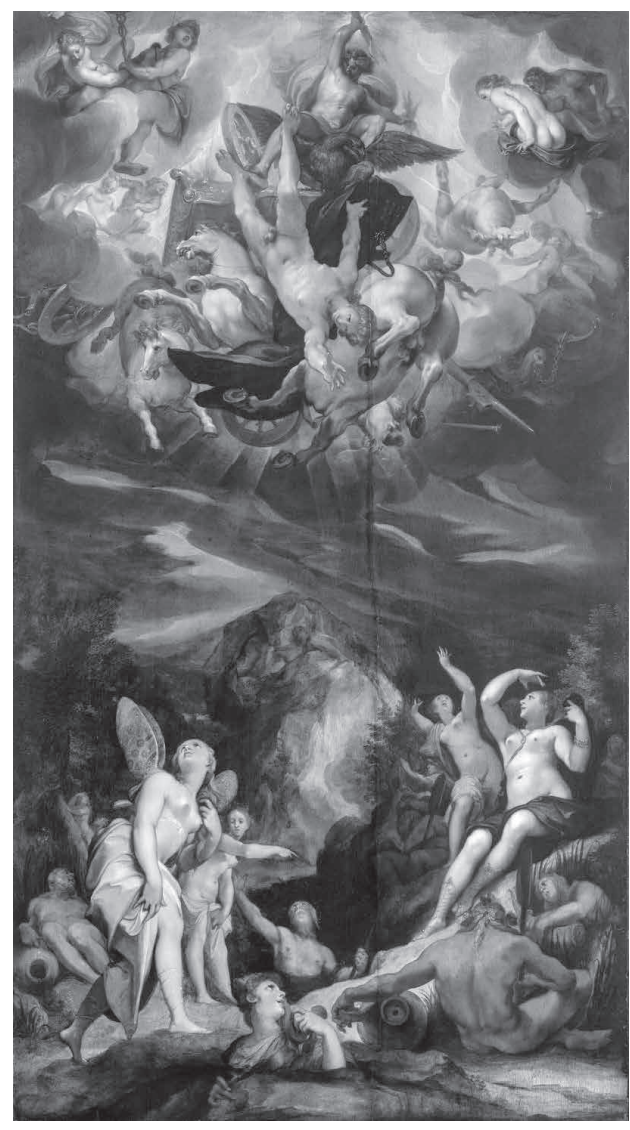

Obrázek 11. Josef Heintz, Faëthontonuv pád, kolem 1600, Leipzig, Museum der Bildenden Künste. Reprodukce $\mathrm{z}$ https://commons.wikimedia .org/wiki/File:Heintz-The_Fall_of_Phaeton.jpg, vyhledáno 11.7.2018

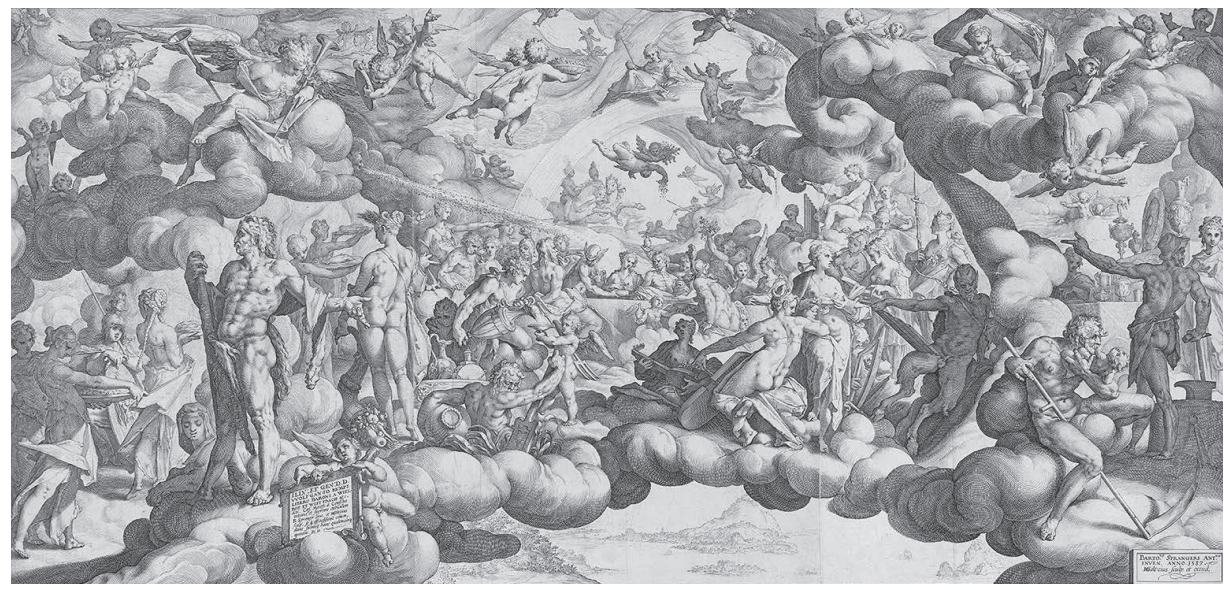

Obrázek 12. Hendrick Goltzius, Svatba Amora a Psyché podle Bartholomea Sprangera, 1587. Reprodukce ze stránek Rijksmuseum Amsterdam, RP-P-1881-A-4866X, http://hdl.handle.net/10934/RM0001 .COLLECT.339347 (CC0 1.0 Universal) 


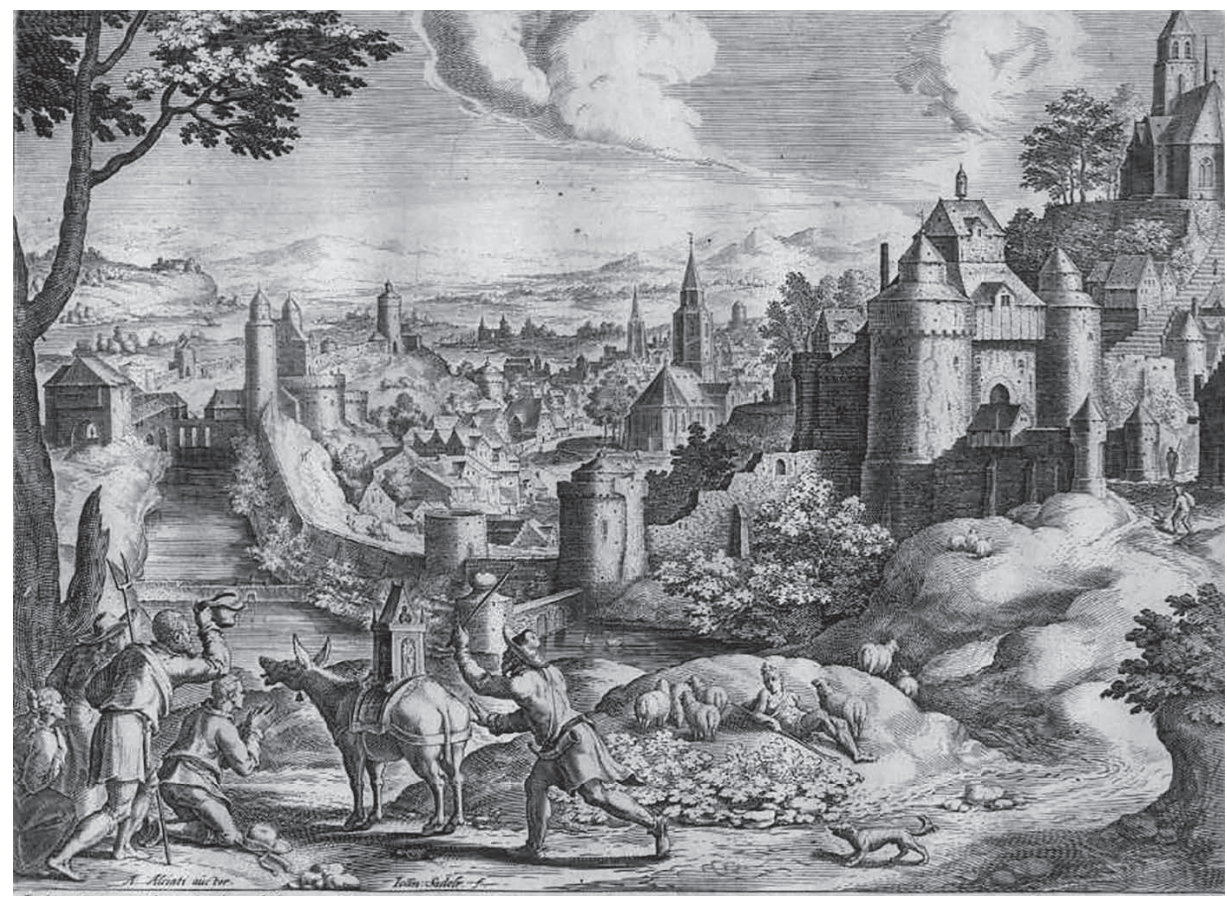

Obrázek 13. Jan Sadeler, Krajina s vesničany uctívajícími bohyni Isidu na oslovi, 1568-1600, Reprodukce ze stati Lubomír Konečný, Adaptations of Alciato's emblems by Jan and Raphael Sadeler, Studia Rudolphina X, 2010, s. 135 